\title{
The type of $A \beta$-related neuronal degeneration differs between amyloid precursor protein (APP23) and amyloid $\beta$-peptide (APP48) transgenic mice
}

Ajeet Rijal Upadhaya ${ }^{1 \dagger}$, Frederik Scheibe ${ }^{1 \dagger}$, Irina Kosterin ${ }^{1}$, Dorothee Abramowski ${ }^{2}$, Janina Gerth ${ }^{3}$, Sathish Kumar ${ }^{3}$, Stefan Liebau ${ }^{4}$, Haruyasu Yamaguchi ${ }^{5}$, Jochen Walter ${ }^{3}$, Matthias Staufenbiel ${ }^{2}$ and Dietmar Rudolf Thal ${ }^{*}$

\begin{abstract}
Background: The deposition of the amyloid $\beta$-peptide $(A \beta)$ in the brain is one of the hallmarks of Alzheimer's disease (AD). It is not yet clear whether $A \beta$ always leads to similar changes or whether it induces different features of neurodegeneration in relation to its intra- and/or extracellular localization or to its intracellular trafficking routes. To address this question, we have analyzed two transgenic mouse models: APP48 and APP23 mice. The APP48 mouse expresses $A \beta_{1-42}$ with a signal sequence in neurons. These animals produce intracellular $A \beta$ independent of amyloid precursor protein (APP) but do not develop extracellular A plaques. The APP23 mouse overexpresses human APP with the Swedish mutation (KM670/671 NL) in neurons and produces APP-derived extracellular A $\beta$ plaques and intracellular $A \beta$ aggregates.

Results: Tracing of commissural neurons in layer III of the frontocentral cortex with the Dil tracer revealed no morphological signs of dendritic degeneration in APP48 mice compared to littermate controls. In contrast, the dendritic tree of highly ramified commissural frontocentral neurons was altered in 15-month-old APP23 mice. The density of asymmetric synapses in the frontocentral cortex was reduced in 3-and 15-month-old APP23 but not in 3- and 18-month-old APP48 mice. Frontocentral neurons of 18-month-old APP48 mice showed an increased proportion of altered mitochondria in the soma compared to wild type and APP23 mice. A 3 was often seen in the membrane of neuronal mitochondria in APP48 mice at the ultrastructural level.

Conclusions: These results indicate that APP-independent intracellular Aß accumulation in APP48 mice is not associated with dendritic and neuritic degeneration but with mitochondrial alterations whereas APP-derived extraand intracellular A $\beta$ pathology in APP23 mice is linked to dendrite degeneration and synapse loss independent of obvious mitochondrial alterations. Thus, A 3 aggregates in APP23 and APP48 mice induce neurodegeneration presumably by different mechanisms and APP-related production of A $\beta$ may, thereby, play a role for the degeneration of neurites and synapses.
\end{abstract}

Keywords: Intracellular amyloid $\beta$-protein, Extracellular amyloid $\beta$-protein, Mitochondria, Dendrites, Toxicity, Degeneration

\footnotetext{
* Correspondence: Dietmar.Thal@uni-ulm.de

${ }^{\dagger}$ Equal contributors

1 Institute of Pathology - Laboratory of Neuropathology, University of UIm,

Ulm, Germany

Full list of author information is available at the end of the article
}

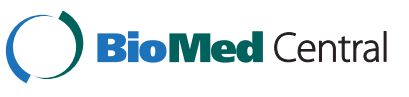

(c) 2013 Rijal Upadhaya et al.; licensee BioMed Central Ltd. This is an Open Access article distributed under the terms of the Creative Commons Attribution License (http://creativecommons.org/licenses/by/2.0), which permits unrestricted use, distribution, and reproduction in any medium, provided the original work is properly cited. The Creative Commons Public Domain Dedication waiver (http://creativecommons.org/publicdomain/zero/1.0/) applies to the data made available in this article, unless otherwise stated. 


\section{Background}

The deposition of amyloid $A \beta$-peptide $(A \beta)$ in the human brain and the formation of neurofibrillary tangles (NFTs) are histopathological hallmarks of Alzheimer's disease (AD) [1,2]. Neuron loss, neuritic and synaptic degeneration are seen in addition to $\mathrm{A} \beta$-plaque deposition and NFT formation and are assumed to represent the morphological correlative of cognitive decline [3-5].

$\mathrm{A} \beta$ is a proteolytic fragment derived from the amyloid precursor protein (APP) by $\beta$ - and $\gamma$-secretase cleavage $[6,7] . A \beta$ is the major component of extracellular senile plaques in the $\mathrm{AD}$ brain [2] and it has been considered to play a central role in $\mathrm{AD}$ pathogenesis [8]. In addition to extracellular $A \beta$-deposition, intracellular $A \beta$ occurs in nerve cells in the AD brain $[9,10]$ and in mouse models for $A D$ [11-13]. The role of intracellular $A \beta$ in neurodegeneration and the development of $\mathrm{AD}$ is discussed controversially. Mutant intracellular $\mathrm{A} \beta$ has been shown to induce hippocampal cell loss associated with endoplasmic reticulum stress and mitochondrial alterations in cell culture [14]. Memory impairment in APP-transgenic mice has been observed even after reduction of plaques. In these animals increased levels of intraneuronal $A \beta$ were reported [15]. The new APP48 mouse model expresses a proenkephalin signal peptide (SPENK)-human wild type $A \beta_{42}$ construct in neurons of the central nervous system (CNS), exhibits intracellular $A \beta$-aggregates in neurons in the absence of $\mathrm{A} \beta$-plaques, and develops CA1 neuron loss and motor deficits [16]. The name APP48 mouse is misleading because $A \beta$ is produced independent from APP in these mice but we used the name APP48 mouse here because this mouse model was already introduced to the scientific community with this name [16]. Although A $\beta$ production in APP48 mice differs from APP-derived $A \beta$ production and does not model AD, APP48 mice allow the analysis of intracellular A $\beta$ toxicity independent of APP under artificial conditions. The APP23 mouse is an A $\beta$-plaque producing mouse model, which overexpresses human APP with the Swedish mutation (KM670/671NL) in CNS neurons. It exhibits dendrite degeneration, loss of CA1 neurons and of asymmetric synapses in the frontocentral cortex [17-19]. In this mouse model $A \beta$ is generated by proteolytic processing of APP by $\beta$ - and $\gamma$-secretases. It accumulates extracellularly in $A \beta$ plaques and in intracellular aggregates $[13,20]$. Together, these mouse models offer the possibility to compare the effect of $A \beta$ placed into the endoplasmic reticulum and the Golgi apparatus in APP48 mice with A $\beta$ cleaved from APP in a post-Golgi compartment $[21,22]$ in APP23 mice. Both mice have been demonstrated to express high amounts of the transgene mRNA in neurons of the neocortex and hippocampus in a similar distribution pattern $[16,20]$ providing comparable transgene expression levels in the respective neurons of these mouse models. Here, we investigated 1) any pathological abnormalities associated with APP-independent intracellular $A \beta$ accumulation in APP48 mice and 2) whether APP and A $\beta$ production by $\beta$ - and $\gamma$-secretase is critical for neurodegeneration in APP23 mice rather than the mere presence of the A $\beta$ peptide as in APP48 mice.

To address these objectives we studied dendritic morphology of frontocentral layer III pyramidal cells and synapse densities in the frontocentral cortex and the hippocampal sector CA1 of APP48 mice in comparison with APP23 and wild type mice. We determined the numbers of neurons in the frontocentral cortex as well as in the hippocampal sector CA1, and compared ultrastructural changes in neurons of APP23, APP48, and wild type mice.

\section{Methods}

\section{Animals}

APP48 mice were generated as described previously [16] and continuously back-crossed to $\mathrm{C} 57 \mathrm{BL} / 6$. A murine Thy-1 expression cassette was used encoding the rat proenkephalin signal sequence followed by human wild type $A \beta_{1-42}$ to drive neuron-specific expression of human wild type $A \beta_{1-42}$. APP23 mice were generated as described previously [20] and continuously back-crossed to $\mathrm{C} 57 \mathrm{BL} / 6$. The same murine Thy- 1 cassette was used to drive neuron-specific expression of human APP751 with the Swedish double mutation 670/671 KM $\rightarrow$ NL. Heterozygous female APP23 mice ( 3 months, $\mathrm{n}=12$; 15 months, $\mathrm{n}=17$ ) and female and male APP48 mice (3 months, $\mathrm{n}=12 ; 18$ months, $\mathrm{n}=17$ ) were analyzed. As control, respective female and male wild type littermates of $3(\mathrm{n}=14), 15(\mathrm{n}=10)$, and 18 months $(\mathrm{n}=10)$ were used.

Animals were treated in agreement with the German and Swiss laws for the use of laboratory animals.

\section{Tissue preparation and Dil tracing}

For DiI tracing the brains of 3 and 18-months-old APP48, 3 and 15-month-old APP23, and of 3 and 15-18month-old wild type mice were studied. Mice were anesthetized. Perfusion was performed transcardially with Tris-buffered saline (TBS) with heparin ( $\mathrm{pH}$ 7.4) followed by the injection of $0.1 \mathrm{M}$ PBS ( $\mathrm{pH} 7.4$ ) containing $2.6 \%$ paraformaldehyde (PFA), $0.8 \%$ iodoacetic acid, $0.8 \%$ sodium periodate and $0.1 \mathrm{M} \mathrm{D-L}$ lysine. The brains were removed in total and post-fixed in $2.6 \%$ phosphatebuffered PFA ( $\mathrm{pH} 7.4$ ) containing $0.8 \%$ iodoacetic acid, $0.8 \%$ sodium periodate and $0.1 \mathrm{M}$ D-L lysine [23]. Three days later a single crystal $\left(0.3 \mathrm{~mm}^{3}\right)$ of the carbocyanine dye DiI (Molecular Probes, Eugene, OR, USA) was implanted into the left frontocentral cortex, $1 \mathrm{~mm}$ rostrally from the central sulcus, $2 \mathrm{~mm}$ laterally from the middle 
line and $1 \mathrm{~mm}$ deep in the cortex as reported earlier [18]. This dye allows precise Golgi-like tracing of neurons in post-mortem fixed tissue in a quality similar to in vivo tracing methods [18]. After incubation in $2.6 \%$ phosphate-buffered PFA for at least 3 months at $37^{\circ} \mathrm{C}$, $100 \mu \mathrm{m}$ thick coronal vibratome sections were cut. All sections of a given mouse brain were separately stored and continuously numbered. Sections were temporarily mounted in TBS for microscopic analysis.

\section{Microscopic and quantitative analysis}

In layer III of the frontocentral cortex of the right hemisphere, contralateral to the implantation site of the tracer, the morphology of traced commissural neurons was examined. The traced neurons were assigned to different types according to their morphology [18] (Additional file 1). Then the number of traced commissural neurons of each type in wild type mice was counted and compared with that in APP23 and APP48 mice. For qualitative and quantitative analysis 10 consecutive sections $(100-\mu \mathrm{m}$ thickness each) representing a tissue block of $1 \mathrm{~mm}$ thickness were studied for each mouse. Analysis started at the anterior commissure setting the caudal limit of the investigated tissue block. For each coronal section, the medial boundary of the region investigated was set as the vertical line at the cingulum that separated the cingulate cortex from secondary motor cortex (M2). The horizontal boundary was set as the horizontal line separating the primary somatosensory cortex (S1) from the insular cortex.

For the qualitative analysis a laser scanning confocal microscope (Leica TCS NT, Leica, Bensheim, Germany) was used. Stacks of 2D images were superimposed digitally using the Image $J$ Image Processing and Analysis software (NIH, Bethesda, MD, USA), and 3D data sets were generated for the visualization of neurons with their entire dendritic tree. For quantification, traced neurons in layer III were counted in the region of interest in 10 consecutive sections of the tissue block taken for qualitative and quantitative analysis using a fluorescence microscope (Leica DMLB, Leica). In so doing, we analyzed a cortex volume of $5-6 \mathrm{~mm}^{3}$ in each mouse. Mean and median values of the number of traced neurons were calculated and compared between wild type, APP23, and APP48 mice.

\section{Immunohistochemistry}

Immunohistochemistry was performed for the visualization of $A \beta$ pathology as well as dendritic morphology in APP48 and APP23 mice. After formic acid pretreatment free-floating sections were incubated in goat anti-mouse immunoglobulin (IgG) to block cross-reactions with intrinsic mouse IgG as previously described [24]. To detect A $\beta$-positive material the sections were stained with monoclonal antibodies specifically detecting the C-terminus of
$\mathrm{A} \beta_{42}$ (MBC42 [25], 1/200). In APP23 mice anti-A $\beta_{17-24}$ (4G8; 1/5000, Sigma-Aldrich, St. Louis, USA) was used to stain $A \beta$-deposits regardless of the $A \beta_{40}$ or $\mathrm{A} \beta_{42}$ C-terminus. MBC40 ([25], 1/20) antibodies detecting exclusively the $C$-terminus of $A \beta_{40}$ were used in APP23 mice as well. N-terminal-truncated and pyroglutamate modified $A \beta_{\mathrm{N} 3 \mathrm{pE}}$ was detected with anti-A $\beta_{\mathrm{N} 3 \mathrm{pE}}$ (polyclonal rabbit, 1/100, additional microwave pretreatment, IBL International GmbH, Hamburg, Germany [26]). Phosphorylation of serine 8 of $A \beta$ was detected with antibodies against phosphorylated $\mathrm{A} \beta$ (pA $\beta$; SA5434, 1/5; $1 \mathrm{E} 4 \mathrm{E} 11,1 / 50$, additional microwave pretreatment $[27,28])$. The primary antibodies were detected with a biotinylated secondary antibody and the ABC complex (Vectastain, Vector laboratories (Burlingame, CA. USA)), and visualized with DAB [29]. Sections were mounted in Eukitt ${ }^{\odot}$ (Kindler, Freiburg, Germany). The immunostained sections were analyzed with a Leica DMLB fluorescence microscope (Leica, Bensheim, Germany). Positive and negative controls were performed.

\section{Protein extraction from brain tissue}

Protein extraction was carried out from female APP23 $(\mathrm{n}=4), \operatorname{APP} 48(\mathrm{n}=4)$, and wild type littermates $(\mathrm{n}=4)$ mouse brains, aged 9-11 months. Mice of this age were taken to demonstrate the differences in the biochemical distribution of A $\beta$ in APP23 and APP48 mice.

Fresh frozen forebrain $(0.4 \mathrm{~g})$ was homogenized in $2 \mathrm{ml}$ of $0.32 \mathrm{M}$ sucrose dissolved in Tris-buffered saline (TBS) containing a protease and phosphatase inhibitorcocktail (Complete and PhosphoSTOP, Roche, Mannheim, Germany) with Micropestle (Eppendorf, Hamburg, Germany) followed by sonication. The homogenate was centrifuged for $30 \mathrm{~min}$ at $14.000 \times \mathrm{g}$ at $4^{\circ} \mathrm{C}$. The supernatant (S1) with the soluble and dispersible fraction not separated from one another was kept. The pellet (P1) containing the membrane-associated and the insoluble, plaque-associated fraction was resuspended in 2\% SDS.

Ultracentrifugation of the supernatant S1 at $175.000 \times$ $\mathrm{g}$ was used to separate the soluble, i.e. the supernatant after ultracentrifugation (S2), from the dispersible fraction, i.e. the resulting pellet (P2). The pellet $\mathrm{P} 2$ with the dispersible fraction was resuspended in TBS.

The SDS-resuspended pellet P1 was centrifuged at $14.000 \times \mathrm{g}$. The supernatant (S3) was kept as membraneassociated SDS-soluble fraction. The pellet (P3) that remained was dissolved in 70\% formic acid and dried in a vacuum centrifuge (Vacufuge, Eppendorf, Hamburg, Germany) and reconstituted in $100 \mu \mathrm{l}$ of $2 \mathrm{X}$ LDS (lithium dodecyl sulfate) sample buffer (Invitrogen, Carlsbad, $\mathrm{CA}$, USA) followed by heating at $70^{\circ} \mathrm{C}$ for $5 \mathrm{~min}$. The resultant sample was considered as insoluble, plaqueassociated fraction [30]. The total protein amounts of soluble, dispersible, and membrane-associated fractions 
were determined using BCA Protein Assay (Bio-Rad, Hercules, CA, USA).

\section{SDS-PAGE and western blot analysis}

For SDS-PAGE, soluble (S2), dispersible (P2), membraneassociated (SDS-soluble; S3), and insoluble, plaqueassociated (formic acid soluble; P3) fractions (50 $\mu \mathrm{g}$ total protein) were electrophoretically resolved in a precast NuPAGE 4-12\% Bis-Tris gel system (Invitrogen). The protein load was controlled either by Ponceau $S$ staining or $\beta$ actin (C4, 1/1000, Santa Cruz Biotechnology, Santa Cruz, CA, USA) immunoblotting.

$A \beta$ was detected by western blotting with anti-A $\beta_{1-17}$ (6E10, Covance, Dedham, USA, 1/1000). Blots were developed with an ECL detection system (Supersignal Pico Western system, ThermoScientific-Pierce, Waltham, MA, USA) and illuminated in ECL Hyperfilm (GE Healthcare, Buckinghamshire, UK).

\section{A $\beta$ ELISA}

For analysis of $A \beta$ by ELISA, forebrain homogenates from APP23 and APP48 mice of each age group (23 months: $\mathrm{n}=6$ (APP23), 6 (APP48); 15-18 months: $\mathrm{n}=7$ (APP23), 8 (APP48)) were homogenized, centrifuged and loaded on sandwich ELISA plates for quantification of $A \beta$ peptides $\left(A \beta_{42}\right.$ : ELISA from Innogenetics, Ghent, Belgium) as previously described [18]. Standard curves were prepared with synthetic $A \beta_{1-42}$ purchased from Bachem and diluted in extracts of non-transgenic mouse forebrain prepared in parallel as described above. Each sample was analyzed in duplicate.

\section{Stereology}

Six APP23, six APP48, and six wild type mice at the ages of 3 and 15-18-months, respectively, were chosen randomly for stereology. One brain section of the frontocentral cortex already quantified for the number of DiI-traced neurons was selected by chance and stained with aldehyde fuchsin-Darrow red. Quantification of neurons was performed according to the principles of unbiased stereology [31]. The frontocentral cortex volume was defined as the volume of the subfields M2, M1, S1 starting at the level of the anterior commissure as described previously [18]. The CA1 volume was measured in serial $100 \mu \mathrm{m}$ thick sections of the entire mouse brain at $5 \mathrm{x}$ magnification. Neurons were counted in three different, randomly chosen microscopic fields (40x objective magnification) of an aldehyde fuchsin - Darrow red stained section of the frontocentral cortex and CA1, respectively. For optical dissection, stacks of 10 images in $2 \mu \mathrm{m}$ focus distance were generated for each microscopic field. Only those neurons having nuclei with dark and round nucleoli visible in the center of soma in one of the stack-images were considered for quantification using the ImageJ software (NIH, Bethesda, USA). The number of neurons in the frontocentral cortex and CA1 was calculated on the basis of the respective reference volumes and neuron densities.

\section{Electron microscopy, immunoelectron microscopy and semiquantitative assessment of synapse densities and mitochondrial alterations}

$100 \mu \mathrm{m}$ thick vibratome sections of the frontocentral cortex and of the hippocampus from six wild type, six APP23, and six APP48 mice, aged 3 and 1518 months respectively, were flat-embedded in Epon (Fluka, Germany). A second vibratome section from each animal and region was flat embedded in LRWhite-Resin (Hard-grade Acrylic Resin; London Resin Company, Berkshire, UK). A part of the frontocentral cortex covering all six cortical layers was dissected under microscopic control and pasted on Epon blocks with a drop of Epon. Likewise, a part of the CA1 subfield of the hippocampus with adjacent stratum oriens and radiatum was cut and pasted on a second Epon block ultrathin sections were cut at $70 \mathrm{~nm}$. Epon sections were block stained with uranyl acetate and lead citrate, and viewed with a Philips EM400T 120KV (Philips, Eindhoven, The Netherlands), a Zeiss EM10 (Zeiss, Oberkochen, Germany), or a JEM-1400 (JEOL, Tokyo, JP) electron microscope. LR-White sections were immunostained with anti-A $\beta_{42}$ (MBC42) and anti-A $\beta_{1-17}$ (6E10, Covance, Dedham, USA, $1 \mathrm{mg} / \mathrm{ml}$ ) antibodies and visualized with anti-mouse secondary antibodies (Aurion Immuno Gold Reagents \& Accessories, Wageningen, The Netherlands) labeled with $10 \mathrm{~nm}$ nanogold particles. Digital pictures were taken.

Digital pictures from Epon embedded sections were taken from 20 soma- and plaque-free neuropil areas located in layers II-VI at 4600-times magnification. The numbers of the symmetric and asymmetric synapses were counted and the length of the synapses was determined with the ImageJ software (NIH, Bethesda, USA). The synaptic density was determined separately for symmetric and asymmetric synapses according to DeFelipe et al. [32] (synaptic density = number of synapse-profiles in a given area / length of synaptic profiles). These semiquantitative data were used to compare the synaptic densities between the different mouse lines. Asymmetric and symmetric synapses were distinguished according to published criteria [33,34].

Synaptic densities in the CA1 regions were measured in 10 randomly taken pictures of the stratum oriens and in 10 randomly taken pictures of the stratum radiatum at 4600-times magnification.

The frequency of dystrophic neurites was observed by counting the number of dystrophic neurites in the 20 pictures taken for the determination of the synapse densities. The criteria for the identification of dystrophic 
neurites at the ultrastructural level were: neurite profiles with a disorganized cytoplasm, occurrence of multilamellar structures in the absence of ultrastructurally intact cell organelles in the area of the lesion, and an enlarged size compared with neighboring neuritic profiles (Figure 1) [19]. Neurites of apoptotic or necrotic neurons, which are not enlarged and do not accumulate multilamellar bodies, were not considered as dystrophic neurites. The number of such dystrophic neurites was determined in six APP23, six APP48 and six wild type mice, aged 3 and 15-18 months respectively, and used as a semiquantitative score for structural neuritic alterations.

To clarify whether APP-independent production of intraneuronal $\mathrm{A} \beta$ or APP-derived extra- and intracellular $A \beta$ accumulation are critical for mitochondrial changes in neurons we compared mitochondrial alterations in frontocentral and CA1 neurons of six APP23, six APP48 and six wild type mice, aged 3 and 15-18 months respectively, at the electron-microscopic level. For this purpose we measured the area profiles from neuritic and somatic neuronal mitochondria as well as from the respective somata and peripheral neurites in plaque-free areas. Mitochondria in peripheral dendrites and axons were analyzed in the 20 pictures from soma- and plaque-free areas of the frontocentral cortex and in 20

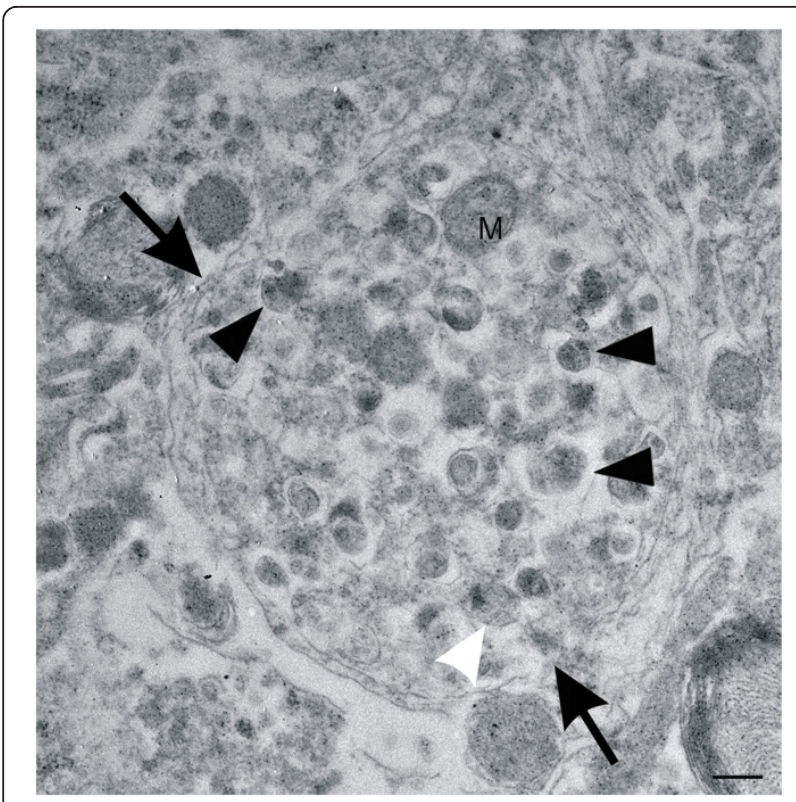

Figure 1 Identification of dystrophic neurites. Electron microscopy was used to identify dystrophic neurites (arrows) as previously described [19] and shown here in the frontocentral cortex of 15-month-old APP23 mice. Such neurites are characterized by neuritic swelling and contain vesicles with electron dense bodies (black arrowheads) probably representing autophagic vacuoles. Mitochondria in these neurites appear morphologically intact (M). Few multivesicular bodies are seen in these neurites as well (white arrowhead). The calibration bar corresponds to: $250 \mathrm{~nm}$. pictures of the stratum oriens and radiatum of the CA1 hippocampal subfield also used for the assessment of synapse densities. The mitochondria in neuronal somata were studied in 40 pictures from 10 different, randomly taken, layer II - layer VI neurons of the frontocentral cortex and in 40 pictures from 10 randomly taken CA1 neurons at 6000-times magnification (4 pictures per neuron) in each individual mouse. The area profiles from morphologically intact mitochondria and from those with an altered ultrastructure, i.e. degeneration of christae as described previously in prion disease [35], were separately obtained for somatic and peripheral neuritic mitochondria. Volume densities in percent of soma and neurite profiles were calculated according to the criteria for unbiased stereology [36] following the determinations provided in Table 1 . Image processing and analysis software was used (ImageJ NIH, Bethesda, MD, USA) for this purpose. Assessments were performed without previous knowledge of the genotypes of the animals.

\section{Statistical analysis}

SPSS 19.0 (SPSS, Chicago, IL, USA) software was used to calculate statistical tests. Non-parametric tests were used to compare wild type, APP23, and APP48 mice. p-values were corrected for multiple testing using the Bonferroni method. Parametric data were analyzed by ANOVA with subsequent Games-Howell post-hoc test to correct for multiple testing or using the Welch test. The results of the statistical analysis are summarized in Additional file 2.

\section{Results}

\section{Different patterns of A $\beta$-pathology in APP23 and APP48 mice}

As previously published 15-month-old APP23 mice exhibited a high number of extracellular $A \beta$-plaques in the cerebral cortex (Figure 2a - indicated by arrows) as well as cerebral amyloid angiopathy as previously described in male and female animals [37]. Intracellular $A \beta_{42}$ detectable with MBC42 was not abundant at the light microscopic level in this region neither in neurons nor in glial cells. MBC40-positive $\mathrm{A} \beta_{40}$ was observed in the perikarya of pyramidal neurons. At 3 months of age APP23 mice did not exhibit A $\beta$ plaques or vascular $A \beta$ deposits as previously described in male and female animals [37]. APP48 mice, on the other hand, did not show $\mathrm{A} \beta$-plaques but intracellular accumulation of $A \beta$ in dendritic threads, somatic granules in neurons, and in microglial $A \beta$-grains at 3 and 18 months of age (Figure $2 b)$ [16]. This pathology was seen in male and female animals.

Modified $A \beta$ such as $A \beta_{\mathrm{N} 3 \mathrm{pE}}$ was detected in a large number of plaques in 15-month-old APP23 mice (Figure 2c). In APP48 mice only few dendritic threads exhibited $A \beta_{N 3 p E}$ at 3 months of age (Figure $2 d$ ) whereas 
Table 1 Determinations of the parameters employed for quantification of mitochondrial alterations in neurites and nerve cell somata

\begin{tabular}{ll}
\hline Percentage of altered mitochondria in nerve cell somata $=$ & $\frac{\left(\sum \text { area of altered mitochondria within nerve cell somata }\right)}{\sum \text { area of all mitochondria within nerve cell somata } \times 100}$ \\
\hline Percentage of altered mitochondria in neurites (axons and dendrites) $=$ & $\frac{\left(\sum \text { area of altered mitochondria within neurites }\right) \times 100}{\sum \text { area of all mitochondria within neurites }}$ \\
\hline Mitochondrial volume density in the nerve cell somata $=$ & $\frac{\left(\sum \text { area of all mitochondria within nerve cell somata }\right) \times 100}{\sum \text { area of nerve cell somata }}$ \\
\hline Mitochondrial volume density in neurites $=$ & $\frac{\left(\sum \text { area of all mitochondria within neurites }\right) \times 100}{\sum \text { area of neurites }}$ \\
\hline Volume density of altered mitochondria in the nerve cell somata $=\quad$ & $\frac{\left(\sum \text { area of altered mitochondria within nerve cell somata }\right) \times 100}{\sum \text { area of nerve cell somata }}$ \\
\hline Volume density of altered mitochondria in neurites $=$ & $\sum$ area of neurites \\
\hline
\end{tabular}

at 18 months of age a significant number of $\mathrm{A} \beta_{\mathrm{N} 3 \mathrm{pE}}$-positive inclusions was observed as shown previously [16]. Phosphorylated A $\beta(\mathrm{pA} \beta)$ in APP23 mice was detected in plaques of 15 months old APP23 mice (Figure 2e). Intraneuronal pA $\beta$ in APP23 mice was apparent as previously reported in APP-PS1 transgenic animals [28]. Only single pA $\beta$-positive threads were stained in 3-month-old APP48 mice (Figure 2f) whereas a few more pA $\beta$-positive threads, grains and somatic granules were observed at 18 months of age.

Biochemical analysis revealed that 3-month-old APP48 mice contained $\sim 70$ times more total $A \beta_{42}$ detected by ELISA than APP23 mice whereas at 15-18 months of age APP23 mice contained $A \beta_{42}$ in a concentration $\sim 17$ fold higher than in APP48 mice (Figure 3a, Additional file $2 \mathrm{a})$.

To document the distribution of $A \beta$ aggregates we analyzed brain homogenates of 9-11-month-old APP23 and APP48 mice for A $\beta$ in the soluble (S2), dispersible (P2), membrane-associated (S3) and insoluble fraction (P3). APP23 mice exhibited soluble, dispersible, membraneassociated and insoluble, plaque-associated A $\beta$ (Figure 3b) as reported previously in detail [19]. In contrast, APP48 mice only exhibited dispersible, membrane-associated and insoluble, aggregated $A \beta$ whereas soluble $A \beta$ was not detectable (Figure 3b).

\section{Degeneration of neurites and asymmetric synapses in APP23 but not in APP48 mice}

Using retrograde tracing with DiI three types of commissural neurons were subclassified as previously published (Additional file 1) [18] in APP23, APP48, and wild type mice. Type I and type II commissural neurons exhibited alterations in the dendritic tree as well as a decrease in number in 15-month-old APP23 mice compared to wild type littermates as previously reported [18] (Figure 4a-f, Additional file 2). Type III commissural neurons did not exhibit differences in their morphological appearance among APP48, APP23, and wild type littermates (Figure 4f). There were no significant differences in the numbers of type I, II, and III commissural neurons in 3- and 18-monthold APP48 mice and in 3-month-old APP23 mice compared to the respective wild type littermates (Figure 4c-i, Additional file 2b). Thus, 15-month-old APP23 mice exhibited dendritic degeneration of frontocentral commissural neurons whereas APP48 mice did not.

To confirm neuritic degeneration we used transmission electron microscopy to compare the presence of dystrophic neurites among APP23, APP48 and wild type mice. The frequency of dystrophic neurites was higher in the frontocentral cortex of 15-month-old APP23 mice when compared to 15-18-month-old APP48 and wild type mice (Figure 5, Additional file 2c). There were no differences in the frequency of dystrophic neurites between APP48 and wild type mice or between 3-monthold animals of each genotype (Figure 5).

Qualitative changes in synapse morphology other than the generation of dystrophic neurites in 15-month-old APP23 mice were not observed. Semiquantitative analysis of the densities of symmetric and asymmetric synapses showed a reduction of the density of asymmetric synapses in the frontocentral cortex of 3 and 15month-old APP23 mice in comparison to WT mice. In the stratum radiatum and oriens of CA1 a similar trend was observed but did not reach significance. Such a reduction of asymmetric synapses was not observed in APP48 mice in comparison to wild type littermates. Moreover, 3-month-old APP48 mice exhibited more asymmetric synapses than wild type controls (Figure 6a, Additional file $2 \mathrm{~d}$ ). There were no significant differences 


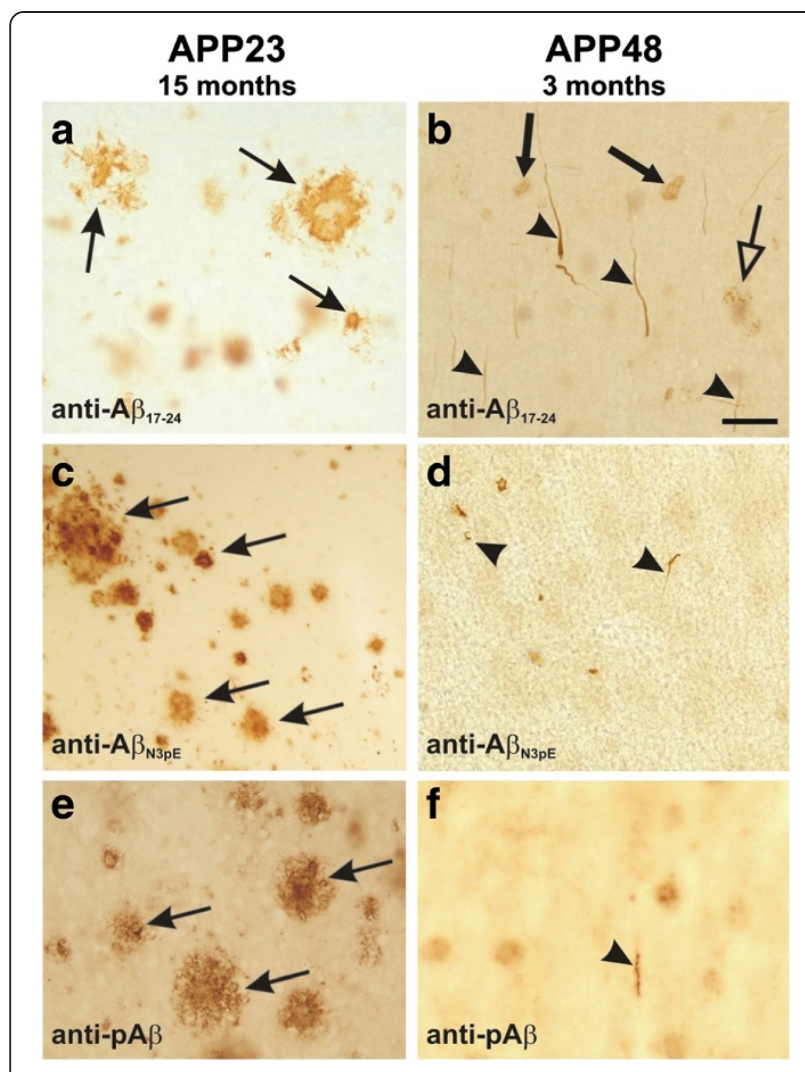

Figure 2 A $\beta$-pathology in 15-month-old APP23 (a, c, e) and 3-month-old-APP48 mice (b, d, f). a: The APP23 mouse showed a high number of extracellular $A \beta$ plaques detectable with an antibody raised against $A \beta_{17-24}$ (arrows). Intracellular $A \beta$ was negligible. b: In the 3-month-old APP48 mouse no extracellular A $\beta$-pathology was apparent. These animals showed intraneuronal dendritic threads (arrowheads) and somatic granules (lucent arrow) as well as intramicroglial $A \beta$-grains (arrows) detectable with anti-A $\beta_{17-24}$ as previously published [16]. c: Amyloid plaques in APP23 mice did also contain $\mathrm{N}$-terminal truncated and pyroglutamate modified $A \beta_{\mathrm{N} 3 \mathrm{pE}}$ (arrows). d: $\mathrm{A} \beta_{\mathrm{N} 3 \mathrm{p} E}$ was also found in even 3-month-old APP48 mice in some neuritic threads (arrowheads). e: phosphorylated $A \beta$ (pA $\beta$ ) was detected in amyloid plaques in 15-month-old APP23 mice. f: In 3-month-old APP48 mice only single threads showed labeling with anti-pA 3 . Calibration bar in b corresponds to: $\mathbf{a}, \mathbf{b}=30 \mu \mathrm{m} ; \mathbf{c}=80 \mu \mathrm{m} ; \mathbf{e}=60 \mu \mathrm{m} ; \mathbf{d}, \mathbf{f}=20 \mu \mathrm{m}$.

in the numbers of symmetric synapses among APP23, APP48, and WT mice (Figure 6b, Additional file 2d).

The number of asymmetric synapses increased with age in the frontocentral neocortex of wild type, APP23, and APP48 mice (Figure 6a, Additional file 2d). Such an increase in the number of asymmetric synapses with age was not seen in the stratum radiatum and oriens of CA1 (Figure 6a, Additional file 2d). The number of symmetric synapses did not differ between 3 and 15-18-month-old mice of each genotype (Figure 6b, Additional file 2d).

Immunoelectron microscopy showed $A \beta$ within dendrites of 15-18-month-old APP23 and APP48 mice. In 15-month-old APP23 mice extracellular A $\beta$ plaques contained fibrillar $A \beta$ that could easily be labeled with

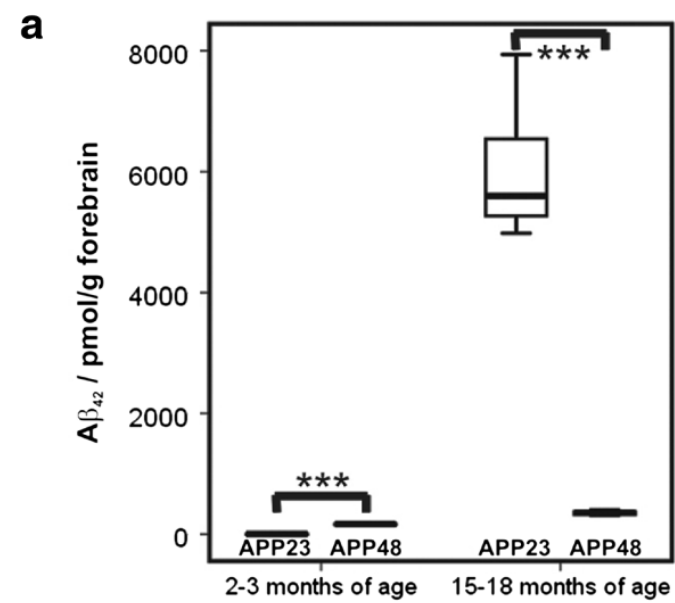

b

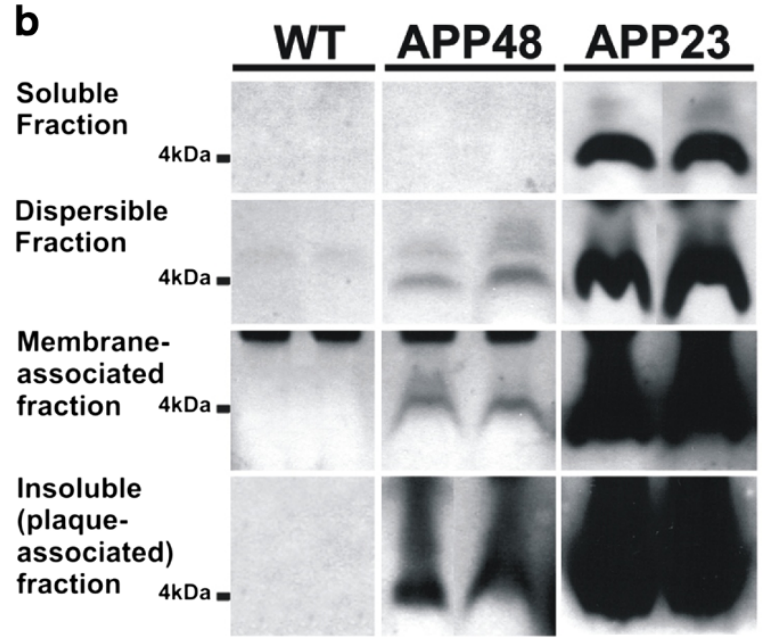

Figure 3 Biochemical analysis of A $\beta$ in APP23 and APP48 mice. a: Total $A \beta_{42}$ levels detected by ELISA in forebrain hemispheres of 2-3 and 15-18-month-old APP23 and APP48 mice. At 2-3 months APP23 mice exhibited low amounts of $A \beta_{42}$ whereas APP48 mice displayed significantly more $A \beta_{42}$ in the brain. At 15-18 months APP48 mice showed more A $\beta$ than at $2-3$ months of age but APP23 mice exhibited several times more $A \beta$ in the forebrain. $\mathbf{b}$ : For demonstration of the types of A $\beta$ aggregates in APP23 and APP48 mice brain homogenates of 9-11-month-old animals were analyzed by SDS-PAGE and western blotting after preparation of the soluble, dispersible, membrane-associated and insoluble (plaque-associated) fraction. Soluble $A \beta$ as detected with antibodies raised against $A \beta_{1-17}$ (6E10) was restricted to APP23 mice. Dispersible, membrane-associated, and insoluble (plaque-associated, formic acid soluble) A $\beta$ aggregates were found in both transgenic mouse lines. The $A \beta$ detected in the insoluble fraction of the forebrain homogenates of APP48 mice represents $A \beta$ aggregates that require formic acid pretreatment before analysis similar to plaque-associated A $\beta$ in APP23 mice. Since APP48 mice did not develop $A \beta$ plaques this insoluble $A \beta$ presumably represented intracellular fibrillar aggregates, such as dendritic threads. Wild type controls did not exhibit detectable amounts of $A \beta$ in all four fractions. The original western blots are depicted in Additional file 3 (ELISA data from APP23 mice were previously published in a different context [18]). ${ }^{* *} p<0.001$ Welch-test. 

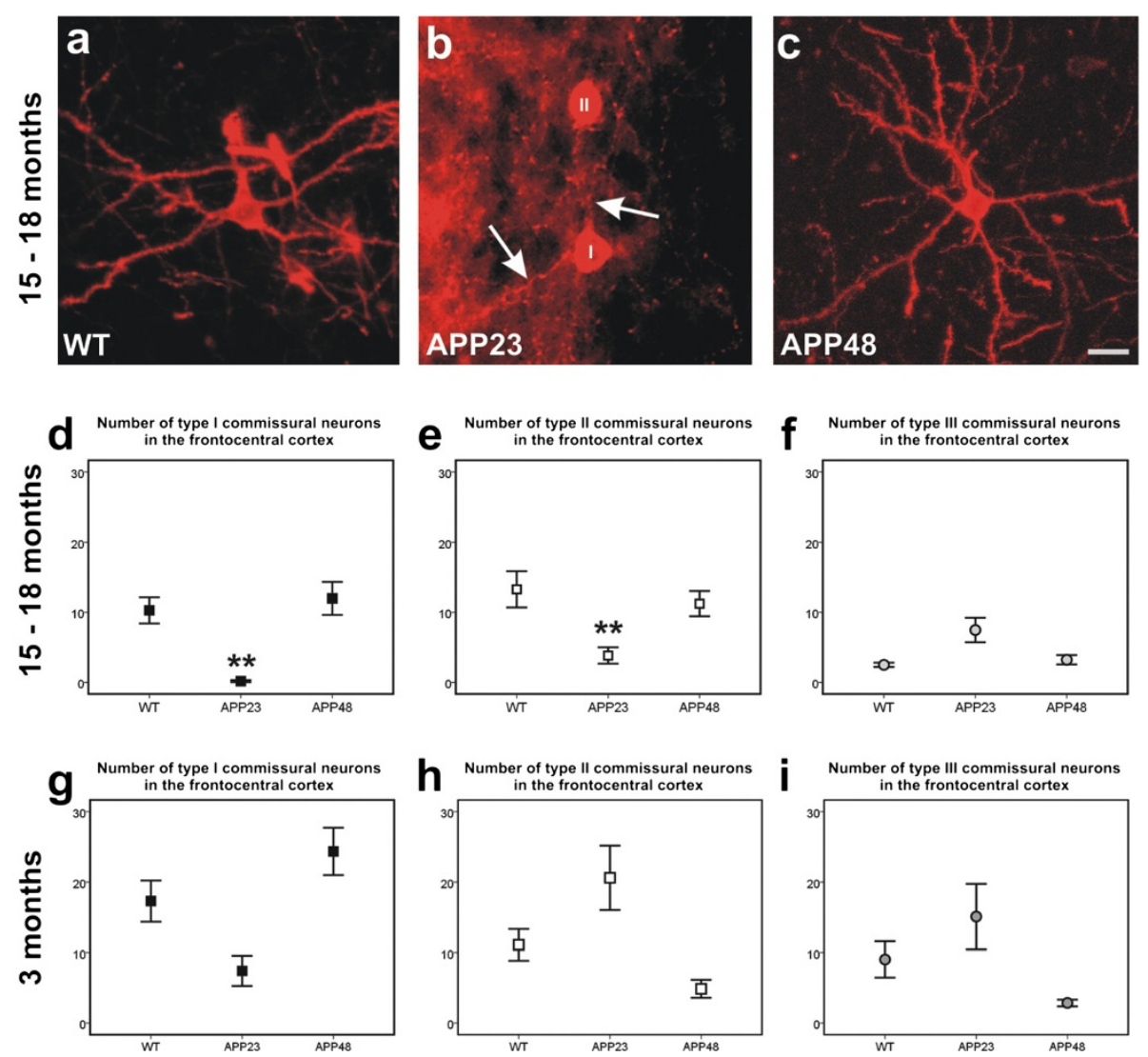

Figure 4 Dendritic degeneration in frontocentral commissural neurons of APP23 and APP48 mice. a: A type I neuron in an 18 month-old wild type animal exhibits a symmetric dendritic tree with prominent secondary and tertiary branches. $\mathbf{b}$ : In contrast, the dendritic tree of a representative type I commissural neuron (I) in a 15-month-old APP23 mouse is degenerated. Most basal dendrites were shrunken and had a reduced caliber (arrows). The degenerated dendrites showed some branches (arrows) that distinguished the degenerated type I neuron (I) from type II neurons without ramifications near the soma (II). c: Such a degeneration of the dendritic tree was not seen in APP48 mice. d-f: Numbers of Dil-traced type I, type II and type III commissural neurons in 15-18-month-old mice. d: APP23 mice at 15 months of age showed a decrease by more than $50 \%$ of the type I commissural neurons compared with 18-month-old wild type and APP48 mice. e: There was a significant reduction of type II commissural neurons in APP23 mice at 15 months of age compared with wild type littermates and APP48 mice at 18 months of age. f: Although APP23 mice had higher numbers of type III commissural neurons there was no significant difference from wild type littermates. $\mathbf{g}$-h: No significant differences among the frequencies of Dil-traced type I, type II, and type III commissural neurons were observed at 3 months of age. ${ }^{* *} p<0.01$ (Further statistical analysis: Additional file 2). Means and standard errors are depicted in $\mathbf{d}$-i. (Quantitative data from APP23 mice and their respective wild type littermates were previously published in a different context [18]). Calibration bar in $\mathbf{c}$ corresponds to: $\mathbf{a}-\mathbf{c}=30 \mu \mathrm{m}$.

anti-A $\beta_{1-17}$ (Figure 7a, b). Plaque-associated dystrophic neurites were seen in the middle of bundles of extracellu$\operatorname{lar} A \beta$ fibrils. No fibrillar $A \beta$ was found within neurites of APP23 mice. However, intracellular A $\beta$ was detected in a few of these dystrophic neurites near the membrane in electron dense spherical particles, which may represent non-fibrillar $A \beta$ oligomers or protofibrils (Figure $7 \mathrm{c}-\mathrm{e}$ ). In APP48 mice fibrillar A $\beta$ aggregates presumably representing the ultrastructural correlate of dendritic threads were found in the dendrites as seen morphologically in Eponembedded tissue. These dendrites were not enlarged (Figure $7 f$ ). Immunoelectron microscopy with anti-A $\beta_{1-17}$ indicated that the fibrillar structures identified in the Epon-embedded sections contain A $\beta$ (Figure 7g) [16]. Organelles near dendritic threads in APP48 mice, thereby, did not differ from that elsewhere in APP48 mouse neurons as demonstrated for a mitochondrium in Figure $7 \mathrm{~g}(\mathrm{~m})$.

\section{Neuron loss in the CA1 subfield but not in the} frontocentral cortex of APP48 and APP23 mice

The number of CA1 neurons was lower in 3- and 18month-old APP48 mice compared to wild type animals indicating CA1 neuron loss in APP48 mice [16]. A decrease in the number of CA1 neurons was also observed in 3- and 15-month-old APP23 mice in comparison to wild type animals (Figure 6c, Additional file 2e) [19].

In contrast, the number of neurons in the frontocentral cortex of 15-18-month-old APP23 and APP48 mice was not significantly different from that in wild type mice (Figure 6d, Additional file 2e) [16]. Therefore, we 


\section{Frequency score of dystrophic neurites}

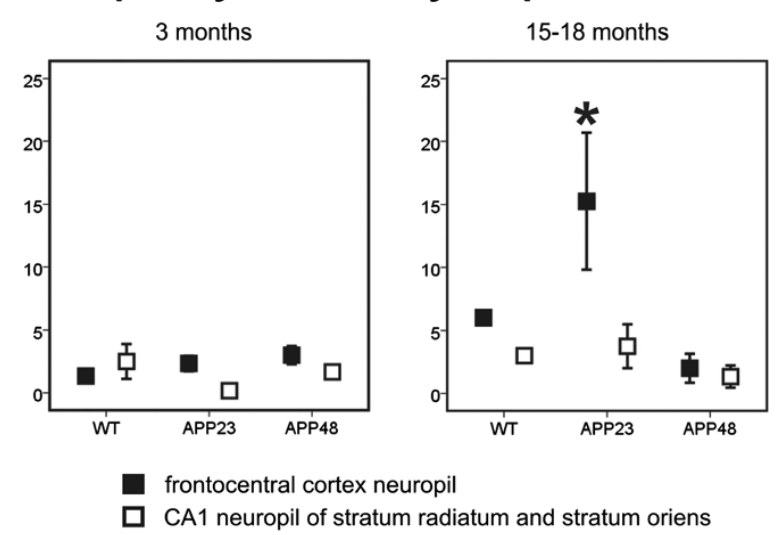

Figure 5 Frequencies of dystrophic neurites in wild type,

APP23, and APP48 mice. The semiquantitatively assessed frequency of dystrophic neurites in the soma- and plaque-free frontocentral neuropil at the electron microscopic level was higher in 15-monthold APP23 mice than in wild type and APP48 mice of the same age group. In APP48 mice there was no increase in the frequency of dystrophic neurites in comparison to wild type mice. 3-month-old mice did not exhibit significant differences in the frequency of dystrophic neurites among the 3 genotypes nor were differences found in neuropil of the stratum radiatum and oriens of the CA1 region. (Data from APP23 mice and their respective wild type littermates were previously published in a different context [19]). ${ }^{*} p<0.05$ (Further statistical analysis: Additional file 2). Means and standard errors are depicted.

did not analyze 3-month-old animals for the numbers of frontocentral neurons.

Increased mitochondrial alterations in neuronal somata of APP48 but not of APP23 mice

The analysis of mitochondrial alterations in neurites and the somata of frontocentral neurons showed differences between 15-18-month-old WT, APP23, and APP48 mice (Figure 8a-f). Increased percentages and volume densities of altered mitochondria exhibiting destruction and rarefaction of the christa membranes as depicted in Figure 8c were observed in somata of neurons from APP48 mice in contrast to predominantly ultrastructurally intact mitochondria in wild type and APP23 mice (Figure 8a, b, d, e, Additional file 2f,g). However, few altered mitochondria were also observed in wild type and APP23 mice. Such an increase in the percentage and volume density of altered mitochondria in APP48 mice was not observed in the hippocampal subfield CA1 and in the frontocentral neocortex of 3-month-old animals (Figure 8d, e, g, h, Additional file 2f, g). Neurites studied distant from nerve cell somata exhibited a small number of altered mitochondria in all mice but did not show differences in the percentage and volume densities of altered mitochondria among the three mouse lines at both ages and locations (Additional file 2i, j, Additional file $3 \mathrm{a}-\mathrm{c})$. The volume densities of somatic and neuritic mitochondria in general, i.e. unaltered and altered mitochondria together, did not significantly differ in APP23, APP48 and wild type mice (Figure 8f, i, Additional file 2h, k, Additional file 3c, f).

In the neuronal somata, the percentages and volume densities of altered mitochondria in frontocentral and CA1 neurons increased with age (Figure $8 d$, e, g, h, Additional file $2 \mathrm{f}, \mathrm{g}$ ). The volume densities of all, altered and healthy-looking mitochondria increased in APP23 and APP48 mice with age whereas in wild type animals such an increase was not observed (Figure 8f, i, Additional file $2 \mathrm{~h}$ ).

In neuritic processes, an increase or at least an increasing trend with age in the percentages and volume densities of altered mitochondria was observed in the frontocentral cortex of APP23, APP48 and wild type mice (Additional file 2k, Additional file 4a, b). In the stratum radiatum and oriens neurites of CA1, the percentages and volume densities of altered mitochondria in 15-month-old APP23 mice were lower than in wild type mice whereas no differences were observed between 3-month-old APP23 and wild type mice as well as between APP48 mice of any age and wild type mice (Additional file 2k, Additional file 4d, e). In neurites, the volume densities of all, healthy-looking and altered mitochondria did not increase with age (Additional file $2 \mathrm{k}$, Additional file 4c, f).

At the electron microscopic level $A \beta$ was detected in lipofuscin granules or in association with other cytoplasmic material in neurons of APP23 (Figure 7c-e, Figure 9j, k) and APP48 mice as previously reported $[16,19,38]$ with or without mitochondrial alterations. Even neurons of wild type mice without detectable $A \beta$ contained single altered mitochondria. In 15-month-old APP23 mice A $\beta$ was seen only in few mitochondria (Figure 9c) whereas most somatic and neuritic mitochondria did not contain $A \beta-$ positive material (Figure 9b). In contrast, altered and non-altered mitochondria labeled for $A \beta$ showing gold particles in association with mitochondrial membranes were often found in the nerve cell somata of 18-monthold APP48 mice (Figure 9d, e).

\section{Discussion}

This study shows that APP-derived extra-and intracellular A $\beta$ pathology in 15-month-old APP23 mice was associated with neuron loss, synapse loss and with neuritic alterations in non-apoptotic and non-necrotic neurons. On the other hand, APP-independent intraneuronal accumulation of $A \beta$ in the absence of $A \beta$ plaques in APP48 mice lead to a loss of neurons in the CA1 region [16] and to mitochondrial alterations but not to neuritic and synaptic degeneration in non-apoptotic and nonnecrotic neurons. Both, extracellular plaques in APP23 

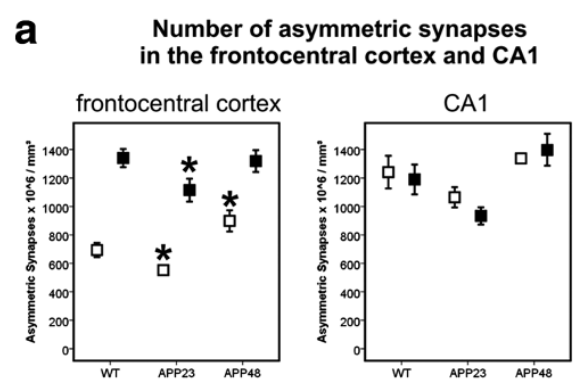

\section{C}

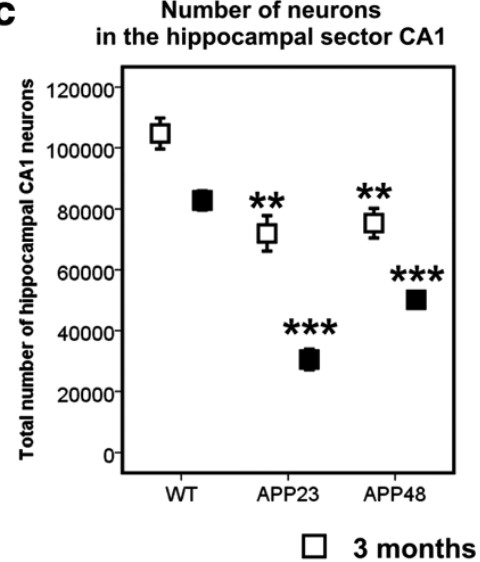

b

Number of symmetric synapses

in the frontocentral cortex and CA1
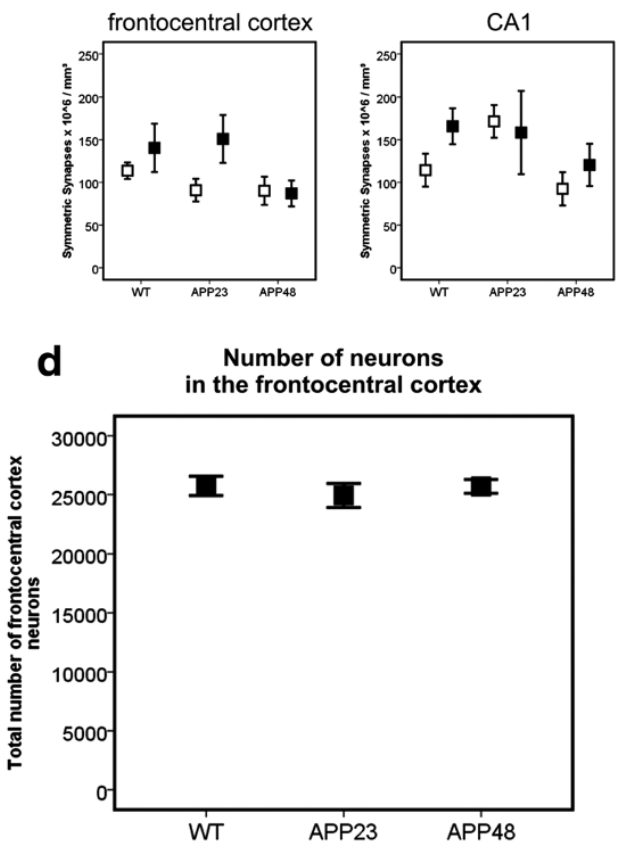

15-18 months

Figure 6 Synapse densities in wild type, APP23 and APP48 mice. a: Loss of asymmetric synapses in the frontocentral cortex of 3-and 15-month-old APP23 mice in comparison to wild type mice. 18-month-old APP48 and wild type mice did not differ significantly in the density of asymmetric synapses. At 3 months of age APP48 mice had even more asymmetric synapses than wild type animals. In CA1 there were also slightly less asymmetric synapses in APP23 mice than in wild type controls and APP48 mice. However, these differences were not significant. $\mathbf{b}$ : There were no significant differences in the number of symmetric synapses in the frontocentral cortex and in CA1 in 3-and 15-18-month-old animals. c: APP23 and APP48 mice of both age groups exhibited reduced numbers of CA1 neurons compared to wild type mice whereby CA1 neuron loss was most pronounced in APP23 mice. $\mathbf{d}$ : The number of neurons in the frontocentral cortex did not vary significantly among 15-18-month-old wild type, APP23, and APP48 mice. Therefore, younger animals were not studied for the number of neurons in the frontocentral cortex. ${ }^{*} p<0.05$, ${ }^{* *} p<0.01,{ }^{* * *} p<0.001$ (Further statistical analysis: Additional file 2). Means and standard errors are depicted. (Some data were previously published in a different context $[16,19])$.

mice and intraneuronal $\mathrm{A} \beta$ in APP48 mice also contained $\mathrm{A} \beta_{\mathrm{N} 3 \mathrm{pE}}$ and $\mathrm{pA} \beta$.

APP23 and APP48 mice differ considerably with respect to the mechanism of transgenic, human $A \beta$ generation. Cleavage of $A \beta$ from APP with the Swedish mutation as in APP23 mice occurs after APP internalization from the membrane in the early endosomal compartment $[22,39]$. Once generated, $A \beta$ is rapidly secreted into the extracellular space to a large extent. In APP48 mice, on the other hand, expression of $A \beta_{42}$ with a cleaved signal sequence targets the released $A \beta$ to the endoplasmic reticulum. Intracellular accumulation occurs in neurites and lysosomes whereas only very little $\mathrm{A} \beta_{42}$ is secreted into the extracellular space [16]. APP48 mice lack human APP and its metabolites except for $\mathrm{A} \beta_{42}$ whereas APP23 mice produce more $A \beta_{40}$ than $\mathrm{A} \beta_{42}$ and, in addition to $A \beta, N$ - and C-terminal fragments of APP. A transgenic mouse expressing only $A \beta_{40}$ with a similar construct as used in APP48 mice for $\mathrm{A} \beta_{42}$ did not show $A \beta$ aggregation and neuronal degeneration [16]. In double transgenic animals, expressing both $A \beta_{42}$ and $A \beta_{40}$ constructs, a similar pattern of pathological lesions was observed as in APP48 mice [16] indicating that $A \beta_{40}$ has only a marginal effect in these animals.

Both, APP23 and APP48 mice exhibited intracellular A $\beta$ in the lysosomal compartment and in mitochondria whereas early endosomal A $\beta$ was not seen in APP48 mice. The distribution of the transgene mRNA in the neocortex and the hippocampus as well as the expression levels were quite similar in APP23 and APP48 mice $[16,20]$. Accordingly, neocortical and hippocampal neurons did not vary much in the transgene expression levels in APP23 and APP48 mice. Both mouse models were used to determine the effects of $A \beta$ under given artificial conditions. None of these two mouse models reflects human AD pathology because none showed significant neurofibrillary tangle pathology and both overexpressed a transgenic construct made to produce large amounts of $A \beta[16,20]$. 


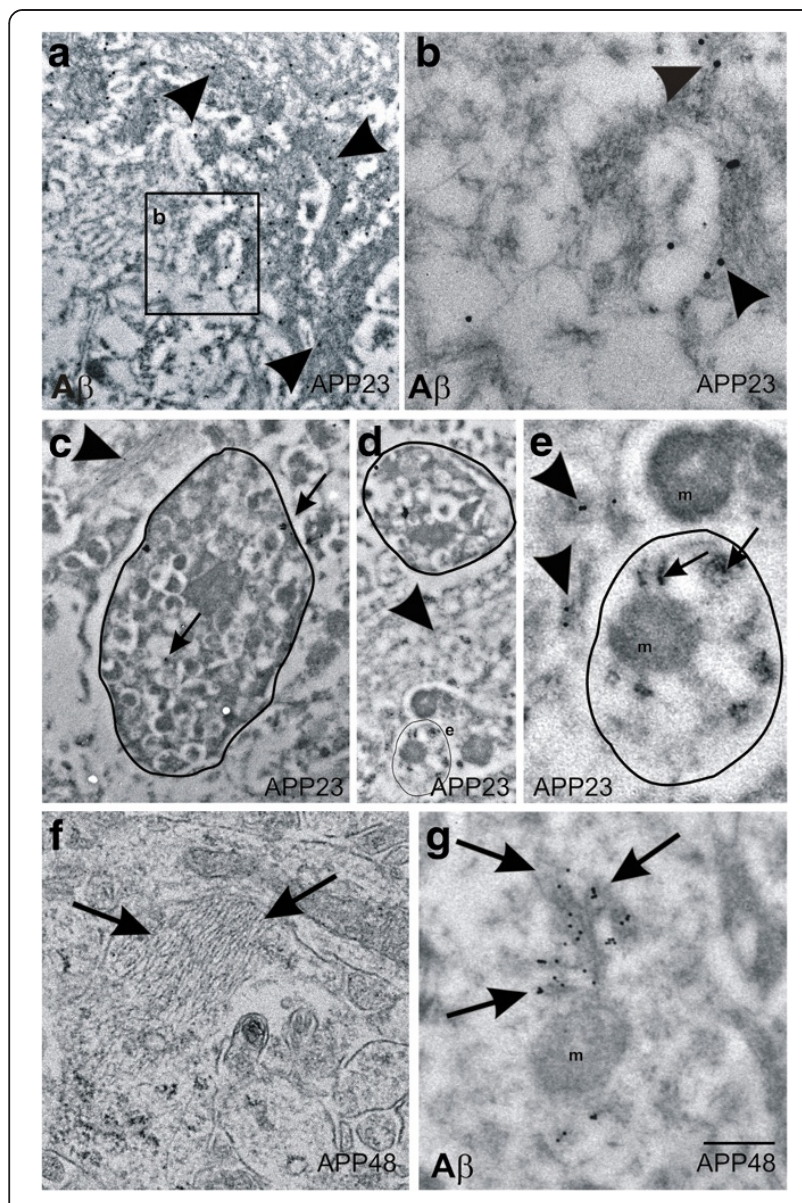

Figure 7 Electron microscopy and immunogold labeling of $A \beta$ in APP23 and APP48 mice. $\mathbf{a}$, b: Immunogold particles specifically labeled fibrillar A (arrowheads) of a plaque in a 15-month-old APP23 mouse. At high magnification small amyloid fibrils were identified (arrowheads in $\mathbf{b}$ ). They were located in the extracellular space. c, d: Dystrophic neurites (outlined structures) were associated with extracellular bundles of plaque-associated $A \beta$ fibrils (arrowheads) in an 15-month-old APP23 mouse. Within the neurite, A $\beta$ was localized in electron dense material near the surface as well as in the center of the neurite (arrows in c). $\mathbf{d}$ : A second dendrite without signs of dystrophy such as multilamellar bodies was also located near extracellular A $\beta$ fibrils (outlined structure labeled with $\mathbf{e}$ ). e: Higher magnification of this dendrite showed a dendrite cross section with an intact mitochondrium $(\mathrm{m})$ and with condensed $A \beta$-positive material in the cytoplasm (arrows). Similar A $\beta$-positive material was found in the neighboring extracellular space (arrowhead). Both, intra- and extracellular $A \beta$ aggregates did not exhibit fibrillar morphology. As such it is quite likely that these $A \beta$ aggregates represent non-fibrillar oligomers and/or protofibrils occurring in the neighborhood of extracellular, plaque-associated A $\mathrm{B}$ fibrils. f: Fibrillar material (arrows) was observed in some dendrites of a 3-month-old APP48 mouse in an Epon-embedded, not immunostained section presumably representing the ultrastructural correlative for dendritic threads. g: Immunoelectron microscopy confirmed Aß-positive material in fibrillar aggregates within dendritic threads labeled by gold particles (arrows) in APP48 mice. No A $\beta$ was observed in the neighboring, non-altered mitochondrium (m). Calibration bar in $\mathbf{g}$ is valid for: $\mathbf{a}=570 \mathrm{~nm}, \mathbf{b}=200 \mathrm{~nm}, \mathbf{c}=750 \mathrm{~nm}, \mathbf{d}=1000 \mathrm{~nm}, \mathbf{e}=275 \mathrm{~nm}$, $\mathbf{f}, \mathbf{g}=350 \mathrm{~nm}$.

\section{Neurite and synapse degeneration in APP23 and APP48 mice}

APP23 mice showed dendritic degeneration in DiI-traced commissural neurons, loss of asymmetric synapses and dystrophic neurites whereas none of these pathologies was observed in APP48 mice. In this context, it is important to note that fibrillar $A \beta$ was present in dendrites of APP48 mice indicating that the mere presence of intracellular $A \beta$ was not sufficient to induce this pathology. Accordingly, neuritic degeneration and loss of asymmetric synapses may either require high concentrations of extracellular $\mathrm{A} \beta_{40 / 42}$ and/or the presence of APP and its metabolites including APP-derived A $\beta$ as in APP23 mice. The amount of total $A \beta_{42}$ determined by ELISA did not explain neuritic degeneration because APP48 mice contained more $\mathrm{A} \beta_{42}$ in the brain than 3-5 months old APP23 mice (see also [18]) although 5-month-old APP23 mice did already exhibit dendrite pathology as previously reported [18]. Consistent with our observations, the prevalence of high levels of extracellular $A \beta$ aggregates, e.g. soluble $A \beta$ oligomers and protofibrils and $A \beta$ plaques have been shown to be associated with altered synapse function [40-42]. Neuritic alterations were frequently seen near amyloid plaques $[43,44]$. The electron microscopic detection of extracellular non-fibrillar and fibrillar $A \beta$-positive aggregates in association with dystrophic neurites in APP23 but not in APP48 mice further argues in favor of a critical role of extracellular $A \beta$ in neuritic degeneration. Electrophysiological changes in response to extracellularly administered $A \beta$-aggregates were mainly reported for excitatory synapses $[41,42]$. Since asymmetric synapses represent mainly excitatory (glutamatergic) synapses [34] the loss of these synapses likely represented the result of toxic interactions with $A \beta$ aggregates. We have detected $A \beta$ within few dystrophic neurites in APP23 mice indicating that we cannot exclude a contribution of intraneuronal $\mathrm{A} \beta$ to neuritic degeneration.

The Bri-A $\beta_{42}$ mouse, that produces only extracellular $A \beta_{42}$ derived from an $A B r i-A \beta_{42}$ construct did not show behavioral changes but $A \beta$ plaques [45]. Bri-A $\beta_{40}$ mice expressing an $\mathrm{ABri}-\mathrm{A} \beta_{40}$ construct did not even develop plaques. These findings may argue against a contribution of extracellular $A \beta$ to $A \beta$ toxicity. However, it is not yet clear whether the $A B r i$-derived $A \beta_{42}$ aggregates contain similar amounts of $A \beta_{N 3 P E}$ and $p A \beta$ as $A \beta$ aggregates in APP23 or APP48 mice, whether APP expression or the presence of both, $A \beta_{42}$ and $A \beta_{40}$, is required for extracellular $A \beta$ toxicity, or whether this mouse model did not produce enough $A \beta_{42}$ to cause symptoms.

$\mathrm{APP}_{\mathrm{E} 693 \Delta}$ transgenic mice produce $\mathrm{A} \beta$ lacking glutamate22 (E22 $\Delta$ ). This mouse model does not develop amyloid plaques but APP-derived intracellular $\mathrm{A} \beta$ aggregates and synapse loss [12]. Exogenous synthetic $A \beta_{\mathrm{E} 22 \Delta}$ also lead to synaptic alterations in hippocampal slice culture experiments or after intraventricular injection [46,47]. As 

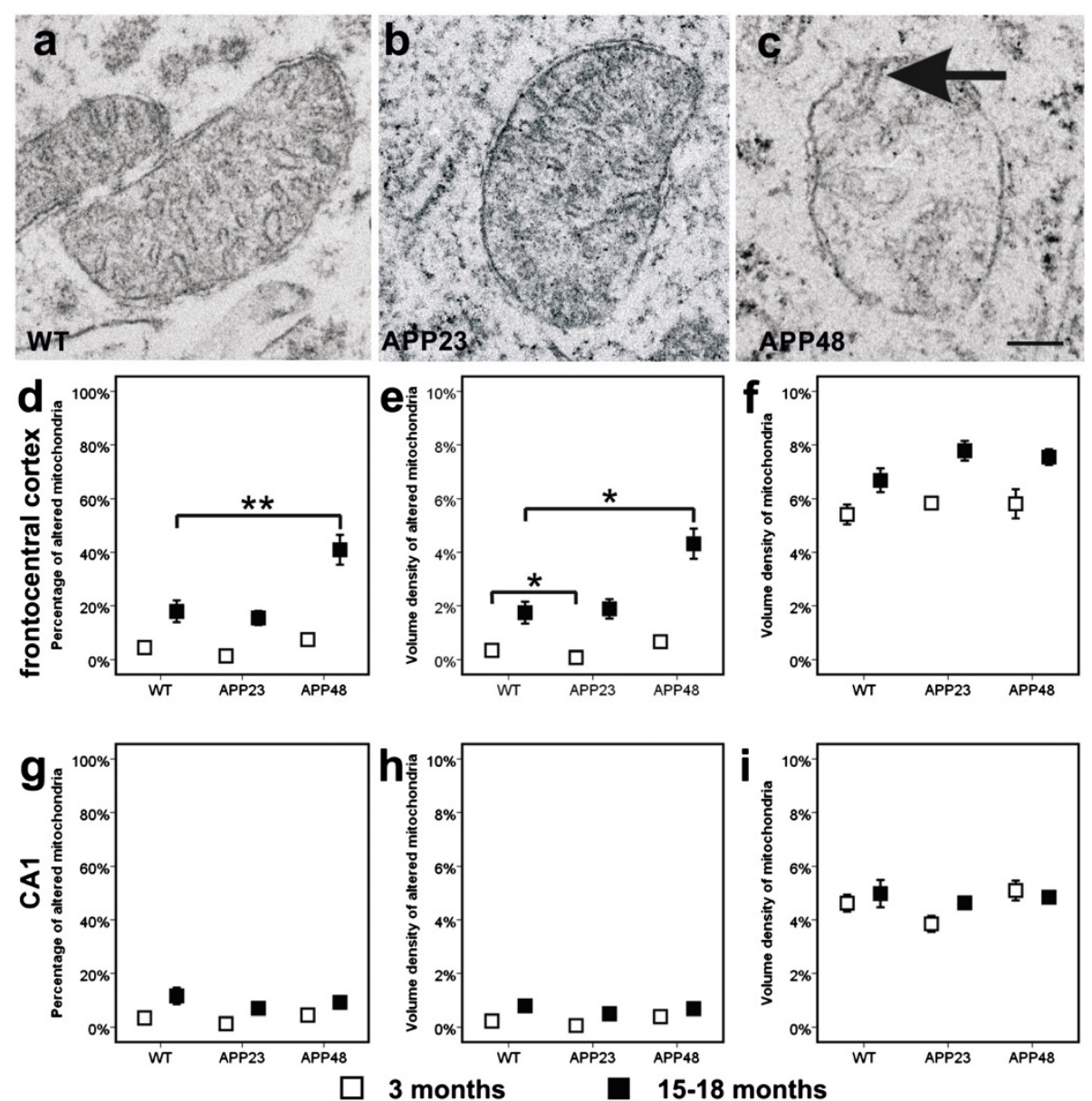

Figure 8 Electron microscopy of mitochondria in wild type, APP23, and APP48 mice. a-b: Electron microscopy showed predominantly nonaltered mitochondria in nerve cell somata of wild type (WT) (a) and APP23 mice (b). c: More altered mitochondria in the nerve cell somata were observed in frontocentral neurons of 18-month-old APP48 mice. Mitochondrial alteration was characterized by a loss of mitochondrial christae although the double membrane architecture and at least single christa structures (arrow) were preserved. $\mathbf{d}$-f: The percentage of altered mitochondria in the nerve cell somata of 18-month-old APP48 mice was higher than in 15-18-month-old wild type and APP23 mice (d). The volume density of altered mitochondria in the frontocentral nerve cell somata of 18-month-old APP48 mice was increased in comparison to 15-18-month-old wild type and APP23 mice (e). At 3 months of age such differences in the presence of altered mitochondria were not observed. The total mitochondrial volume density, i.e. altered and non-altered mitochondria together, did not differ among the investigated mouse lines in both age groups (f). g-i: In CA1 there were no obvious changes in the percentage and volume density of altered mitochondria in the nerve cell somata. ${ }^{*} p<0.05$, ${ }^{* *} p<0.01$ (Further statistical analysis: Additional file 2). Means and standard errors are depicted in $\mathbf{d}$-f. Calibration bar in $\mathbf{c}$ is valid for: $\mathbf{a}-\mathbf{c}=150 \mathrm{~nm}$.

such, neuritic changes and/or synapse pathology can be explained by APP-derived $\mathrm{A} \beta$ production regardless of the presence of $A \beta$ plaques whereas such changes were not reported in $A P P 48, B r i-A \beta_{42}$ and Bri- $\mathrm{A} \beta_{40}$ mice, which produce non-APP derived $A \beta$. A further argument for a role of APP in A $\beta$ toxicity in APP23 mice is our recent finding of a coaggregation of $A \beta$ with $C$-terminal APP fragments in dispersible $A \beta$ aggregates [19] supporting the hypothesis that APP is a molecular target of $A \beta$ toxicity [48].

\section{Mitochondrial alterations in APP23 and APP48 mice}

APP-independent intraneuronal $A \beta$ production and accumulation in 18-month-old APP48 mice was associated with more abundant structural mitochondrial alterations in somata of frontocentral nerve cells compared to APP23 and wild type mice. The increase of mitochondrial alterations in APP48 mice, however, was accompanied by the detection of $A \beta$ in a moderate number of altered and non-altered neuronal somatic mitochondria whereas only few somatic mitochondria in APP23 mice exhibited $A \beta$ and none in wild type animals. Several arguments suggest that the increase of mitochondrial alterations in APP48 mice was related to the presence of $A \beta$ and may have functional consequences: 1 ) $A \beta$ is capable of inducing apoptosis through the mitochondrial-caspase-3 pathway $[49,50], 2)$ mitochondrial $A \beta$ levels are associated with the extent of mitochondrial 


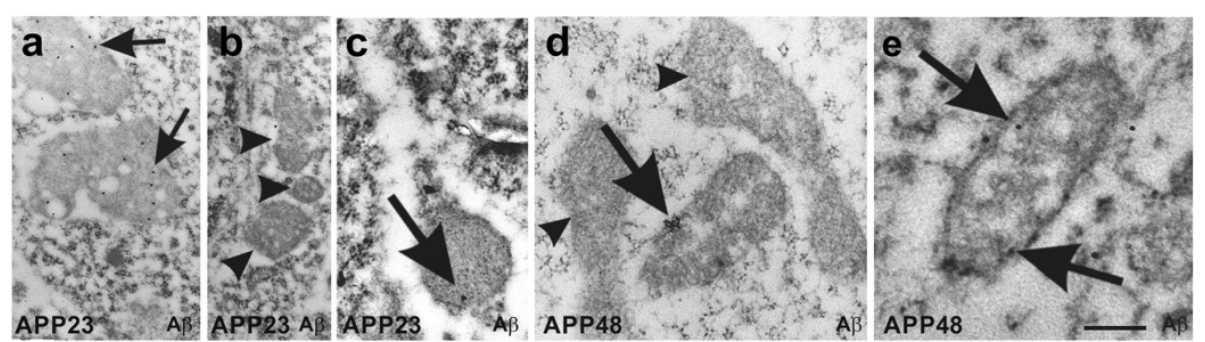

Figure 9 Immunoelectron microscopy of mitochondria in wild type, APP23, and APP48 mice. a: Immunoelectron microscopy revealed gold-labeled A (arrows) within lipofuscin-like granules in the cytoplasm of frontocentral pyramidal neurons in 15-month-old APP23 mice. b. Most mitochondria in the somata of frontocentral pyramidal neurons in 15-month-old APP23 mice did not contain immunogold labeled A -positive material (arrowheads). c: Only few neuronal mitochondria exhibited single gold particles in a 15-month-old APP23 mouse indicating anti-A 3 positive material within these mitochondria (arrow). $\mathbf{d}$ : In a few mitochondria within frontocentral pyramidal nerve cell somata of 18-month-old APP48 mice we found immunogold labeled A $\beta$-positive material associated with the membranes of healthy-looking mitochondria (arrow). Neighboring non-altered mitochondria often did not contain $A \beta$ (arrowheads). $A \beta$ fibrils were not seen inside the mitochondria. e: Altered mitochondria within pyramidal neurons in the frontocentral cortex of a 18-month-old APP48 mouse also exhibited single gold particles in association with their membranes indicating the presence of $A \beta$ (arrows) although $A \beta$ fibrils were not observed inside the mitochondria. Due to the use of LR-white embedded tissue required for post-embedding immunoelectron microscopy $(\mathbf{a}, \mathbf{b})$ the tissue preservation was less good than in the Epon embedded sections used for the morphological analysis of the mitochondria (Figure 8a-c). Calibration bar in $\mathbf{e}$ is valid for: $\mathbf{a}, \mathbf{b}=540 \mathrm{~nm}$, $\mathbf{c}=325 \mathrm{~nm}, \mathbf{d}=288 \mathrm{~nm}, \mathbf{e}=180 \mathrm{~nm}$.

dysfunction, oxidative stress and cognitive impairment in other AD mouse models and $\mathrm{AD}$ [51-55], and 3) histologically altered mitochondria showed a reduced number of christa membranes presumably providing a morphological correlate for an impairment of mitochondrial function; they were found most frequently in APP48 mice which also contained more mitochondrial A $\beta$ than APP23 mice. For APP23 mice, however, we cannot rule out that trophic effects reported for APP expression [56] compensate $A \beta$ toxicity to mitochondria.

It is noteworthy that only mitochondria in the nerve cell somata showed increased alterations in APP48 mice whereas mitochondria in distal dendrites and axons did not exhibit differences in volume density as well as in the percentage of alterations among APP23, APP48, and wild type mice. Thus, APP-independent, intraneuronal $A \beta_{42}$ exhibited its major toxic effects on mitochondria close to its production site in APP48 mice, i.e. close to the endoplasmic reticulum. Biochemical assessment of respiratory chain complex I and complex IV, $\alpha$-ketoglutarate dehydrogenase, and tricarboxylic acid cycle enzyme activity in APP48 and wild type mice did not show significant differences in forebrain homogenates (data not shown). However, the local effect in the soma is probably not sufficient to reduce the overall activities in a brain homogenate.

\section{Two types of $A \beta$-induced neurodegeneration in the frontocentral cortex: somatic type and neuritic type} In the frontocentral cortex of APP23 mice neuritic degeneration and asymmetric synapse loss was found in the absence of neuron loss suggesting that both events indicate a neuritic type of nerve cell degeneration with neuritic degeneration preceding nerve cell death. APP48 mice, on the other hand, showed a different type of nerve cell damage characterized by morphologically altered mitochondria in the cell soma and thread-like $A \beta$ aggregates in dendrites. Although the appearance of the dendrites and axons was, except for the $A \beta$ threads, morphologically normal and no synapse loss was observed, mitochondrial changes in nerve cell somata represented early signs of a somatic type of neurodegeneration. Since mitochondrial alterations caused by $A \beta$ have been demonstrated to induce apoptosis $[49,50]$ it is tempting to speculate that this type of somatic neurodegeneration with increased amounts of morphologically altered mitochondria finally results in apoptosis without the development of dystrophic neurites and dendrite degeneration before cell death. Hence, APP23 mice and APP48 mice develop two different types of nerve cell degeneration in the frontocentral cortex (Figure 10): 1) APP23 mice showed a neuritic type of neurodegeneration with early neuritic and synaptic degeneration but without increased numbers of altered mitochondria; 2) APP48 mice exhibited a somatic type of neurodegeneration with increased somatic mitochondrial degeneration but morphologically intact dendrites and axons.

APP48 and APP23 mice both showed neuron loss in the CA1 region as previously described $[16,17,19]$. It was not accompanied by a reduction in synaptic density suggesting replacement of lost synapses by surviving neurons. Except for A $\beta$ plaques in APP23 mice and intracellular $A \beta$ in both transgenic animals, significant reduction of synapse densities and mitochondrial alterations could not be identified in this brain region possibly because the more vulnerable CA1 neurons die faster than altered neurons in the frontocentral cortex 


\section{Somatic type of neurodegeneration Neuritic type of neurodegeneration

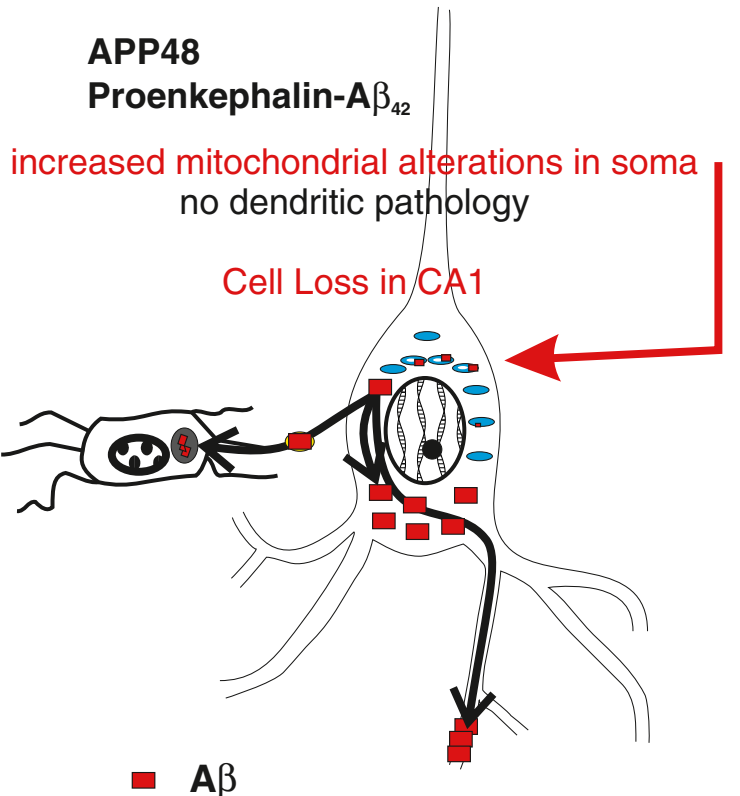 \\ APP23 $_{\text {sw }}$
hAPP $_{\text {sw }}$ \\ dendritic degeneration (reuptake of $A \beta$ ) no increased alterations in somatic mitochondria $\Gamma$ dystrophic neurites (often near plaques)

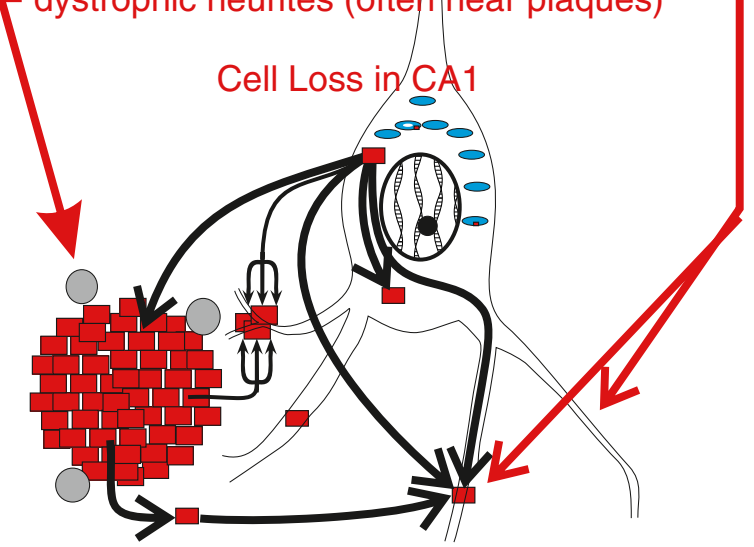 \\ - Non-soluble (presumably microsomal) A $\beta$ of the dispersible fraction \\ mitochondrium \\ altered mitochondrium \\ dystrophic neurite}

Figure 10 Schematic representation of the somatic and neuritic type of $A \beta$-related neurodegeneration in frontocentral neurons of APP23 and APP48 mice. In APP48 mice A $\beta$ accumulates within neurons and in microglial cells as previously reported [16]. Extracellular A $\beta$ is not detectable suggesting that APP-independently produced intracellular A leads to functional impairment of neurons as indicated by motor deficits [16]. Mitochondrial alterations occur more frequently in the nerve cell somata of APP48 mice than in wild type and APP23 mice and are proposed to lead to apoptotic cell death as suggested previously [14] without preceding neuritic alteration. This type of somatic neurodegeneration in APP48 mice is different from that seen in APP23 mice, which contain less intracellular A $\beta$ but significant amounts of extracellular A $\beta$ aggregates including plaques. We propose that extra- and intracellular APP-derived A $\beta$ causes synapse loss, dendrite degeneration and often plaque-associated, dystrophic neurites in APP23 mice indicative for a second neuritic type of neurodegeneration. Intracellular Aß in APP23 mice may be produced within the nerve cell or may be taken up from the extracellular space [13,57-59].

and do not accumulate at early stages of nerve cell degeneration. Since 3-month-old animals have more CA1 neurons than 15-18-month-old mice (Figure 6c) and the decrease in number was higher than the age-related loss of CA1 neurons in wild type mice it appears likely that the age-related loss of CA1 neurons is enhanced by $A \beta$ toxicity in APP23 and APP48 mice.

Although both types of $\mathrm{A} \beta$-related neurodegeneration were observed in artificial mouse models that were made to produce large amounts of $A \beta$ there are arguments for the hypothesis that both mechanisms of $A \beta$-related neurodegeneration are relevant in $A D: 1)$ synapse loss and dystrophic neurites especially around neuritic plaques are well known features of $\mathrm{AD}$ pathology $[3,60,61]$ that might be explained in part by the neuritic type of $A \beta$ related neurodegeneration and 2) mitochondrial alterations are well known in $\mathrm{AD}$ cases as well [54] presumably indicative for somatic type neurodegeneration in the presence of intracellular $A \beta[10]$.

\section{Conclusions}

Our data suggest two independent mechanisms by which $A \beta$ causes neurodegeneration (Figure 10): a neuritic type and a somatic type. The neuritic type of neurodegeneration is characterized by a loss of asymmetric synapses, degeneration of dendrites, occurrence of dystrophic neurites and is associated with the occurrence of APP-derived extra- and intracellular $A \beta$ aggregates in APP23 mice. The somatic type of neurodegeneration shows mitochondrial alterations in the neuronal soma but no changes in neurite morphology of non-necrotic and non-apoptotic cells. It is linked to intraneuronal accumulation of APP-independently produced $A \beta$ and functional changes in APP48 mice [16]. Both mechanisms may 
finally lead to a loss of neurons as observed in the hippocampal sector CA1 in APP23 and APP48 mice [16,17]. Although these mechanisms for $A \beta$-related neurodegeneration have been found under artificial conditions in $A \beta$ producing mouse models it is tempting to speculate that similar mechanisms occur in AD. APP-related production of extra- and/or intracellular $A \beta$, thereby, appears to be critical for neuritic and synaptic degeneration. As such, for the development of therapeutic strategies aimed at protecting neurons from $\mathrm{AD}$-related degeneration it appears important to consider both types of $A \beta$-related neurodegeneration.

\section{Additional files}

Additional file 1: Types of commissural neurons in the frontocentral cortex as previously described [18].

Additional file 2: Statistical analysis.

Additional file 3: Western blot analysis of soluble, dispersible, membrane-associated, and insoluble (plaque-associated) $A \beta$ in wildtype, APP48 and APP23 mice. Original blots related to Figure 3b.

Additional file 4: Mitochondrial alterations in peripheral neurites. a-c: Percentage of altered mitochondria (a), volume densities of altered mitochondria (b), and volume densities of all mitochondria (c) in peripheral neurites did not show significant changes among frontocentral neurons in wild type (WT), APP23 and APP48 mice. d-f: No significant differences in the percentage of altered mitochondria (d), volume densities of altered mitochondria (e), and volume densities of all mitochondria ( $f$ ) in peripheral neurites of the CA1 sector of the Ammon's horn were found between APP48 mice and wild type controls. 3-monthold APP23 mice had less morphologically altered mitochondria (d, e) than wild type controls. In 15-month-old animals the trend was still visible but did not reach significance (d, e). ${ }^{*} \mathrm{p}<0.05$ (Further statistical analysis: Additional file 2).

\section{Competing interests}

D. R. Thal received consultant honorary from Simon-Kucher and Partners (Germany), and GE-Healthcare (UK).

D. Abramowski, and M. Staufenbiel are or have been employees of the Novartis Pharma AG, Basel, Switzerland.

This study was supported by DFG-grants TH624/6-1 (DRT), WA1477/6 (JW) and Alzheimer Forschung Initiative Grants \#10810 (DRT) and \#12854 (SK).

\section{Authors' contributions}

Neuropathology and immunohistochemistry: ARU, IK, JG, SK, HY, JW, DRT; animal breeding, genotyping and brain removal: DA, MS, DRT; Tracing and Laser Scan Microscopy: ARU, SL, DRT; Electron microscopy, immunoelectron microscopy and quantitative analyses: FS, IK, DRT; manuscript preparation: ARU, FS, MS, DRT; critical review of the manuscript: IK, DA, JG, SK, SL, HY, JW; study design, coordination and fund raising: MS, DRT. All authors read and approved the final manuscript.

\section{Acknowledgments}

The authors thank Mr. E. Schmid (Department of Electron Microscopy, University of UIm) for help with electron microscopy and Dr. E. Capetillo-Zarate (Weill Medical College of Cornell University, New York, USA) for technical help and for reading the manuscript.

\section{Author details}

${ }^{1}$ Institute of Pathology - Laboratory of Neuropathology, University of UIm, Ulm, Germany. ${ }^{2}$ Novartis Institutes for Biomedical Research, Basel, Switzerland. 'Department of Neurology, University of Bonn, Bonn, Germany. ${ }^{4}$ Institute of Anatomy and Cell Biology, University of Ulm, Ulm, Germany.

${ }^{5}$ Gunma University School of Health Sciences, Gunma, Japan.
Received: 2 November 2013 Accepted: 6 November 2013

Published: 18 November 2013

\section{References}

1. Alzheimer A: Über eine eigenartige Erkrankung der Hirnrinde. Allg Zschr Psych 1907, 64:146-148.

2. Masters CL, Simms G, Weinman NA, Multhaup G, McDonald BL, Beyreuther $\mathrm{K}$ : Amyloid plaque core protein in Alzheimer disease and Down syndrome. Proc Natl Acad Sci USA 1985, 82:4245-4249.

3. DeKosky ST, Scheff SW: Synapse loss in frontal cortex biopsies in Alzheimer's disease: correlation with cognitive severity. Ann Neurol 1990 27:457-464.

4. Masliah E, Terry RD, DeTeresa RM, Hansen LA: Immunohistochemical quantification of the synapse-related protein synaptophysin in Alzheimer disease. Neurosci Lett 1989, 103:234-239.

5. Terry RD, Peck A, DeTeresa R, Schechter R, Horoupian DS: Some morphometric aspects of the brain in senile dementia of the Alzheimer type. Ann Neurol 1981, 10:184-192.

6. Haass C, Koo EH, Mellon A, Hung AY, Selkoe DJ: Targeting of cell-surface beta-amyloid precursor protein to lysosomes: alternative processing into amyloid-bearing fragments. Nature 1992, 357:500-503.

7. Kang J, Lemaire HG, Unterbeck A, Salbaum JM, Masters CL, Grzeschik KH, Multhaup G, Beyreuther K, Muller-Hill B: The precursor of Alzheimer's disease amyloid A4 protein resembles a cell-surface receptor. Nature 1987, 325:733-736.

8. Hardy J, Selkoe DJ: The amyloid hypothesis of Alzheimer's disease: progress and problems on the road to therapeutics. Science 2002, 297:353-356.

9. D'Andrea MR, Nagele RG, Wang HY, Lee DH: Consistent immunohistochemical detection of intracellular beta-amyloid42 in pyramidal neurons of Alzheimer's disease entorhinal cortex. Neurosci Lett 2002, 333:163-166.

10. Gouras GK, Tsai J, Naslund J, Vincent B, Edgar M, Checler F, Greenfield JP, Haroutunian V, Buxbaum JD, Xu H, Greengard P, Relkin NR: Intraneuronal Abeta42 accumulation in human brain. Am J Pathol 2000, 156:15-20

11. Takahashi RH, Milner TA, Li F, Nam EE, Edgar MA, Yamaguchi H, Beal MF, Xu H, Greengard P, Gouras GK: Intraneuronal Alzheimer abeta42 accumulates in multivesicular bodies and is associated with synaptic pathology. Am J Pathol 2002, 161:1869-1879.

12. Tomiyama T, Matsuyama S, Iso H, Umeda T, Takuma H, Ohnishi K, Ishibashi K, Teraoka R, Sakama N, Yamashita T, Nishitsuji K, Ito K, Shimada H, Lambert $\mathrm{MP}$, Klein $\mathrm{WL}$, Mori $\mathrm{H}$ : A mouse model of amyloid beta oligomers: their contribution to synaptic alteration, abnormal tau phosphorylation, glial activation, and neuronal loss in vivo. J Neurosci 2010, 30:4845-4856.

13. Wirths O, Multhaup G, Czech C, Blanchard V, Moussaoui S, Tremp G, Pradier L, Beyreuther K, Bayer TA: Intraneuronal Abeta accumulation precedes plaque formation in beta-amyloid precursor protein and presenilin-1 double-transgenic mice. Neurosci Lett 2001, 306:116-120.

14. Umeda T, Tomiyama T, Sakama N, Tanaka S, Lambert MP, Klein WL, Mori H: Intraneuronal amyloid beta oligomers cause cell death via endoplasmic reticulum stress, endosomal/lysosomal leakage, and mitochondrial dysfunction in vivo. J Neurosci Res 2011, 89:1031-1042.

15. Tampellini D, Capetillo-Zarate E, Dumont M, Huang Z, Yu F, Lin MT, Gouras GK: Effects of synaptic modulation on beta-amyloid, synaptophysin, and memory performance in Alzheimer's disease transgenic mice. J Neurosci 2010, 30:14299-14304.

16. Abramowski D, Rabe S, Rijal Upadhaya A, Reichwald J, Danner S, Staab D Capetillo-Zarate E, Yamaguchi H, Saido TC, Wiederhold KH, Thal DR, Staufenbiel M: Transgenic expression of intraneuronal Abeta42 but not Abeta40 leads to cellular Abeta lesions, degeneration and functional impairment without typical Alzheimer's disease pathology. J Neurosci 2012, 32:1273-1283.

17. Calhoun ME, Wiederhold KH, Abramowski D, Phinney AL, Probst A, Sturchler-Pierrat C, Staufenbiel M, Sommer B, Jucker M: Neuron loss in APP transgenic mice. Nature 1998, 395:755-756.

18. Capetillo-Zarate E, Staufenbiel M, Abramowski D, Haass C, Escher A, Stadelmann C, Yamaguchi H, Wiestler OD, Thal DR: Selective vulnerability of different types of commissural neurons for amyloid beta-protein induced neurodegeneration in APP23 mice correlates with dendritic tree morphology. Brain 2006, 129:2992-3005.

19. Rijal Upadhaya A, Capetillo-Zarate E, Kosterin I, Abramowski D, Kumar S, Yamaguchi H, Walter J, Fändrich M, Staufenbiel M, Thal DR: Dispersible 
amyloid $\beta$-protein oligomers, protofibrils, and fibrils represent diffusible but not soluble aggregates: Their role in neurodegeneration in amyloid precursor protein (APP) transgenic mice. Neurobiol Aging 2012, $33: 2641-2660$

20. Sturchler-Pierrat C, Abramowski D, Duke M, Wiederhold KH, Mistl C, Rothacher S, Ledermann B, Burki K, Frey P, Paganetti PA, Waridel C, Calhoun ME, Jucker M, Probst A, Staufenbiel M, Sommer B: Two amyloid precursor protein transgenic mouse models with Alzheimer disease-like pathology. Proc Natl Acad Sci USA 1997, 94:13287-13292.

21. Haass C, Lemere CA, Capell A, Citron M, Seubert P, Schenk D, Lannfelt L, Selkoe DJ: The Swedish mutation causes early-onset Alzheimer's disease by beta-secretase cleavage within the secretory pathway. Nat Med 1995 1:1291-1296.

22. Rajendran L, Honsho M, Zahn TR, Keller P, Geiger KD, Verkade P, Simons K: Alzheimer's disease beta-amyloid peptides are released in association with exosomes. Proc Natl Acad Sci USA 2006, 103:11172-11177.

23. Galuske RA, Schlote W, Bratzke H, Singer W: Interhemispheric asymmetries of the modular structure in human temporal cortex. Science 2000, 289:1946-1949.

24. Thal DR, Larionov S, Abramowski D, Wiederhold KH, van Dooren T, Yamaguchi H, Haass C, van Leuven F, Staufenbiel M, Capetillo-Zarate E: Occurrence and co-localization of amyloid beta-protein and apolipoprotein $\mathrm{E}$ in perivascular drainage channels of wild-type and APP-transgenic mice. Neurobiol Aging 2007, 28:1221-1230.

25. Yamaguchi H, Sugihara S, Ogawa A, Saido TC, Ihara Y: Diffuse plaques associated with astroglial amyloid beta protein, possibly showing a disappearing stage of senile plaques. Acta Neuropathol 1998, 95:217-222.

26. Saido TC, Iwatsubo T, Mann DM, Shimada H, Ihara Y, Kawashima S: Dominant and differential deposition of distinct beta-amyloid peptide species, A beta N3(pE), in senile plaques. Neuron 1995, 14:457-466.

27. Kumar S, Rezaei-Ghaleh N, Terwel D, Thal DR, Richard M, Hoch M, Mc Donald JM, Wullner U, Glebov K, Heneka MT, Walsh DM, Zweckstetter M, Walter J: Extracellular phosphorylation of the amyloid beta-peptide promotes formation of toxic aggregates during the pathogenesis of Alzheimer's disease. EMBO J 2011, 30:2255-2265.

28. Kumar S, Wirths O, Theil S, Gerth J, Bayer TA, Walter J: Early intraneuronal accumulation and increased aggregation of phosphorylated Abeta in a mouse model of Alzheimer's disease. Acta Neuropathol 2013, 125:699-709.

29. Hsu SM, Raine L, Fanger H: Use of avidin-biotin-peroxidase complex (ABC) in immunoperoxidase techniques: a comparison between $A B C$ and unlabeled antibody (PAP) procedures. J Histochem Cytochem 1981, 29:577-580

30. Mc Donald JM, Savva GM, Brayne C, Welzel AT, Forster G, Shankar GM, Selkoe DJ, Ince PG, Walsh DM: The presence of sodium dodecyl sulphatestable Abeta dimers is strongly associated with Alzheimer-type dementia. Brain 2010, 133:1328-1341.

31. Schmitz C, Hof PR: Recommendations for straightforward and rigorous methods of counting neurons based on a computer simulation approach. J Chem Neuroanat 2000, 20:93-114.

32. DeFelipe J, Marco P, Busturia I, Merchan-Perez A: Estimation of the number of synapses in the cerebral cortex: methodological considerations. Cereb Cortex 1999, 9:722-732.

33. Colonnier M: Synaptic patterns on different cell types in the different laminae of the cat visual cortex. An electron microscope study. Brain Res 1968, 9:268-287.

34. Miranda R, Sebrie C, Degrouard J, Gillet B, Jaillard D, Laroche S, Vaillend C: Reorganization of inhibitory synapses and increased PSD length of perforated excitatory synapses in hippocampal area CA1 of dystrophindeficient mdx mice. Cereb Cortex 2009, 19:876-888.

35. Siskova Z, Mahad DJ, Pudney C, Campbell G, Cadogan M, Asuni A, O'Connor $\checkmark$, Perry VH: Morphological and functional abnormalities in mitochondria associated with synaptic degeneration in prion disease. Am J Pathol 2010 177:1411-1421.

36. Weibel ER: Stereological principles for morphometry in electron microscopic cytology. Int Rev Cytol 1969, 26:235-302.

37. Sturchler-Pierrat C, Staufenbiel M: Pathogenic mechanisms of Alzheimer's disease analyzed in the APP23 transgenic mouse model. Ann N Y Acad Sci 2000, 920:134-139.

38. Huang SM, Mouri A, Kokubo H, Nakajima R, Suemoto T, Higuchi M, Staufenbiel M, Noda Y, Yamaguchi H, Nabeshima T, Saido TC, Iwata N: Neprilysin-sensitive synapse-associated amyloid-beta peptide oligomers impair neuronal plasticity and cognitive function. J Biol Chem 2006, 281:17941-17951.

39. Rajendran L, Annaert W: Membrane trafficking pathways in Alzheimer's disease. Traffic 2012, 13:759-770.

40. Lacor PN, Buniel MC, Chang L, Fernandez SJ, Gong Y, Viola KL, Lambert MP Velasco PT, Bigio EH, Finch CE, Krafft GA, Klein WL: Synaptic targeting by Alzheimer's-related amyloid beta oligomers. J Neurosci 2004, 24:10191-10200.

41. Shankar GM, Li S, Mehta TH, Garcia-Munoz A, Shepardson NE, Smith I, Brett FM, Farrell MA, Rowan MJ, Lemere CA, Regan CM, Walsh DM, Sabatini BL, Selkoe DJ: Amyloid-beta protein dimers isolated directly from Alzheimer's brains impair synaptic plasticity and memory. Nat Med 2008, 14:837-842.

42. Wang HW, Pasternak JF, Kuo H, Ristic H, Lambert MP, Chromy B, Viola KL, Klein WL, Stine WB, Krafft GA, Trommer BL: Soluble oligomers of beta amyloid (1-42) inhibit long-term potentiation but not long-term depression in rat dentate gyrus. Brain Res 2002, 924:133-140.

43. Spires TL, Meyer-Luehmann M, Stern EA, McLean PJ, Skoch J, Nguyen PT, Bacskai BJ, Hyman BT: Dendritic spine abnormalities in amyloid precursor protein transgenic mice demonstrated by gene transfer and intravital multiphoton microscopy. J Neurosci 2005, 25:7278-7287.

44. Tsai J, Grutzendler J, Duff K, Gan WB: Fibrillar amyloid deposition leads to local synaptic abnormalities and breakage of neuronal branches. Nat Neurosci 2004, 7:1181-1183.

45. McGowan E, Pickford F, Kim J, Onstead L, Eriksen J, Yu C, Skipper L, Murphy MP, Beard J, Das P, Jansen K, DeLucia M, Lin W-L, Dolios G, Wang R, Eckman CB, Dickson DW, Hutton M, Hardy J, Golde T: A 342 is essential for parenchymal and vascular amyloid deposition in mice. Neuron 2005, 47:191-199.

46. Takuma H, Teraoka R, Mori H, Tomiyama T: Amyloid-beta E22Delta variant induces synaptic alteration in mouse hippocampal slices. Neuroreport 2008, 19:615-619.

47. Tomiyama T, Nagata T, Shimada H, Teraoka R, Fukushima A, Kanemitsu $H_{\text {, }}$ Takuma H, Kuwano R, Imagawa M, Ataka S, Wada Y, Yoshioka E, Nishizaki T, Watanabe $Y$, Mori H: A new amyloid beta variant favoring oligomerization in Alzheimer's-type dementia. Ann Neurol 2008, 63:377-387.

48. Bignante EA, Heredia F, Morfini G, Lorenzo A: Amyloid beta precursor protein as a molecular target for amyloid beta-induced neuronal degeneration in Alzheimer's disease. Neurobiol Aging 2013, 34:2525-2537.

49. Costa RO, Ferreiro $E_{1}$ Cardoso SM, Oliveira CR, Pereira CM: ER stressmediated apoptotic pathway induced by Abeta peptide requires the presence of functional mitochondria. J Alzheimers Dis 2010, 20:625-636.

50. Wang ZF, Yin J, Zhang Y, Zhu LQ, Tian Q, Wang XC, Li HL, Wang JZ: Overexpression of tau proteins antagonizes amyloid-beta-potentiated apoptosis through mitochondria-caspase-3 pathway in N2a cells. J Alzheimers Dis 2010, 20:145-157.

51. Caspersen C, Wang N, Yao J, Sosunov A, Chen X, Lustbader JW, Xu HW, Stern D, McKhann G, Yan SD: Mitochondrial Abeta: a potential focal point for neuronal metabolic dysfunction in Alzheimer's disease. FASEB J 2005, 19:2040-2041

52. Dragicevic N, Mamcarz M, Zhu Y, Buzzeo R, Tan J, Arendash GW, Bradshaw PC: Mitochondrial amyloid-beta levels are associated with the extent of mitochondrial dysfunction in different brain regions and the degree of cognitive impairment in Alzheimer's transgenic mice. J Alzheimers Dis 2010, 20(Suppl 2):S535-S550.

53. Du H, Guo L, Fang F, Chen D, Sosunov AA, McKhann GM, Yan Y, Wang C, Zhang H, Molkentin JD, Gunn-Moore FJ, Vonsattel JP, Arancio O, Chen JX, Yan SD: Cyclophilin D deficiency attenuates mitochondrial and neuronal perturbation and ameliorates learning and memory in Alzheimer's disease. Nat Med 2008, 14:1097-1105.

54. Lustbader JW, Cirilli M, Lin C, Xu HW, Takuma K, Wang N, Caspersen C, Chen X, Pollak S, Chaney M, Trinchese F, Liu S, Gunn-Moore F, Lue LF, Walker DG, Kuppusamy P, Zewier ZL, Arancio O, Stern D, Yan SS, Wu H: ABAD directly links Abeta to mitochondrial toxicity in Alzheimer's disease. Science 2004, 304:448-452.

55. Manczak M, Anekonda TS, Henson E, Park BS, Quinn J, Reddy PH: Mitochondria are a direct site of A beta accumulation in Alzheimer's disease neurons: implications for free radical generation and oxidative damage in disease progression. Hum Mol Genet 2006, 15:1437-1449.

56. Mattson MP: Cellular actions of beta-amyloid precursor protein and its soluble and fibrillogenic derivatives. Physiol Rev 1997, 77:1081-1132.

57. Ovsepian SV, Antyborzec I, O'Leary VB, Zaborszky L, Herms J, Oliver Dolly J: Neurotrophin receptor p75 mediates the uptake of the amyloid beta 
(Abeta) peptide, guiding it to lysosomes for degradation in basal forebrain cholinergic neurons. Brain Struct Funct 2013. ehead of print: doi:10.1007/s00429-013-0583-x.

58. Ovsepian SV, Herms J: Drain of the brain: low-affinity p75 neurotrophin receptor affords a molecular sink for clearance of cortical amyloid beta by the cholinergic modulator system. Neurobiol Aging 2013, 34:2517-2524.

59. Tampellini D, Magrane J, Takahashi RH, Li F, Lin MT, Almeida CG, Gouras GK: Internalized antibodies to the Abeta domain of APP reduce neuronal Abeta and protect against synaptic alterations. J Biol Chem 2007, 282:18895-18906.

60. Dickson DW: The pathogenesis of senile plaques. J Neuropathol Exp Neurol 1997, 56:321-339.

61. Wang D, Munoz DG: Qualitative and quantitative differences in senile plaque dystrophic neurites of Alzheimer's disease and normal aged brain. J Neuropathol Exp Neurol 1995, 54:548-556.

doi:10.1186/2051-5960-1-77

Cite this article as: Rijal Upadhaya et al:: The type of $A \beta$-related neuronal degeneration differs between amyloid precursor protein (APP23) and amyloid $\beta$-peptide (APP48) transgenic mice. Acta Neuropathologica Communications 2013 1:77.

\section{Submit your next manuscript to BioMed Central and take full advantage of:}

- Convenient online submission

- Thorough peer review

- No space constraints or color figure charges

- Immediate publication on acceptance

- Inclusion in PubMed, CAS, Scopus and Google Scholar

- Research which is freely available for redistribution 